\title{
Mitochondrion: A Promising Target for Nanoparticle-Based Vaccine Delivery Systems
}

\author{
Ru Wen ${ }^{1}$, Afoma C. Umeano ${ }^{1}$, Lily Francis ${ }^{1}$, Nivita Sharma ${ }^{1}$, Smanla Tundup ${ }^{2}$ \\ and Shanta Dhar ${ }^{1, *}$ \\ 1 NanoTherapeutics Research Laboratory, Department of Chemistry, University of Georgia, Athens, GA 30602, \\ USA; soso2012@uga.edu (R.W.); aumeano@uga.edu (A.C.U.); lgf39148@uga.edu (L.F.); \\ nivita.sharma97@uga.edu (N.S.) \\ 2 School of Medicine, Department of Pulmonary and Critical Care, University of Virginia, Charlottesville, \\ WV 22908, USA; st2vk@virginia.edu \\ * Correspondence: shanta@uga.edu; Tel.: +1-706-542-1012
}

Academic Editor: Diane M. Harper

Received: 8 February 2016; Accepted: 8 April 2016; Published: 1 June 2016

\begin{abstract}
Vaccination is one of the most popular technologies in disease prevention and eradication. It is promising to improve immunization efficiency by using vectors and/or adjuvant delivery systems. Nanoparticle (NP)-based delivery systems have attracted increasing interest due to enhancement of antigen uptake via prevention of vaccine degradation in the biological environment and the intrinsic immune-stimulatory properties of the materials. Mitochondria play paramount roles in cell life and death and are promising targets for vaccine delivery systems to effectively induce immune responses. In this review, we focus on NPs-based delivery systems with surfaces that can be manipulated by using mitochondria targeting moieties for intervention in health and disease.
\end{abstract}

Keywords: vaccine; mitochondria targeting; nanoparticles; antigen delivery

\section{Introduction}

Vaccines are designed immunogenic antigens used to intentionally trigger the memory component of the immune system by stimulating humoral immunity via the production of antibodies for long term protection against various diseases [1] (Figure 1). Attenuated or inactivated vaccine can elicit immunoprotection but duration of effect is limited and concerted to cellular immune responses [2]. Vectors and/or adjuvant delivery systems are widely used to augment immunogenicity of antigens, to protect vaccines from degradation in physiological environment, to improve efficacy of vaccines, and to target specific sites preventing unwanted accumulation [3].

For effective therapeutic use, vectors should be stable, biodegradable, biocompatible, easy to prepare, low cost, immunologically inert, and/or serve synergistically as an adjuvant. Nanoparticle (NP)-based payload cargos and adjuvants for vaccines are growing technologies due to their intrinsic immune-stimulatory properties, ability to co-entrap antigen adjuvants such as toll-like receptor (TLR) and enhancement of the antigen uptake by cells, e.g., by professional antigen presenting cell (APC) manipulation [4-6].

Mitochondria play essential roles for life and death processes of cells. This complex organelle participate in energy generation, intermediary metabolism, exchange of information, calcium signaling, and regulation of apoptosis [7-9]. Mitochondria-associated dysfunctions provide a predictable prospectus of defects in tissues for many ailments, spanning from subtle alterations causing symptomatic illness, to major functional defects leading to death [10,11]. Mitochondria play an important role in the immune system, which involves signaling platforms, effector responses [12], and modulating the antigen-specific T cell activation via reactive oxygen species (ROS) signaling [13,14]. 
Mitochondrial antigens, such as M2 autoantigens [15], oxo-acid dehydrogenase complexes [16] and 2-oxoglutarate dehydrogenase complex [17], are known to induce disease-related autoimmune responses such as primary biliary cirrhosis (PBC) [15-19]. The targets located in the different compartments of mitochondria for possible vaccine development are listed in Table 1. There are reports of mitochondria-targeted NP systems with the ability to produce tumor associated antigens (TAAs) that have the potential to act as preventive/therapeutic vaccines [20]. A mitochondria targeted vaccine was recently reported to stimulate the immune response by mitochondrial DNA (mtDNA) mutations upon immunization in a renal cancer murine model [21]. Such findings support previous studies performed by West et al. illustrating that mtDNA stress primes immune response [22], which may be critical to encourage effective immune stimulation, modulation, and memory-like protection in the context of vaccines. Therefore, mitochondria are promising targets for vaccine delivery systems to effectively induce immunity against diseases and to establish and/or boost therapeutic effects.

\section{NP-based vaccine}

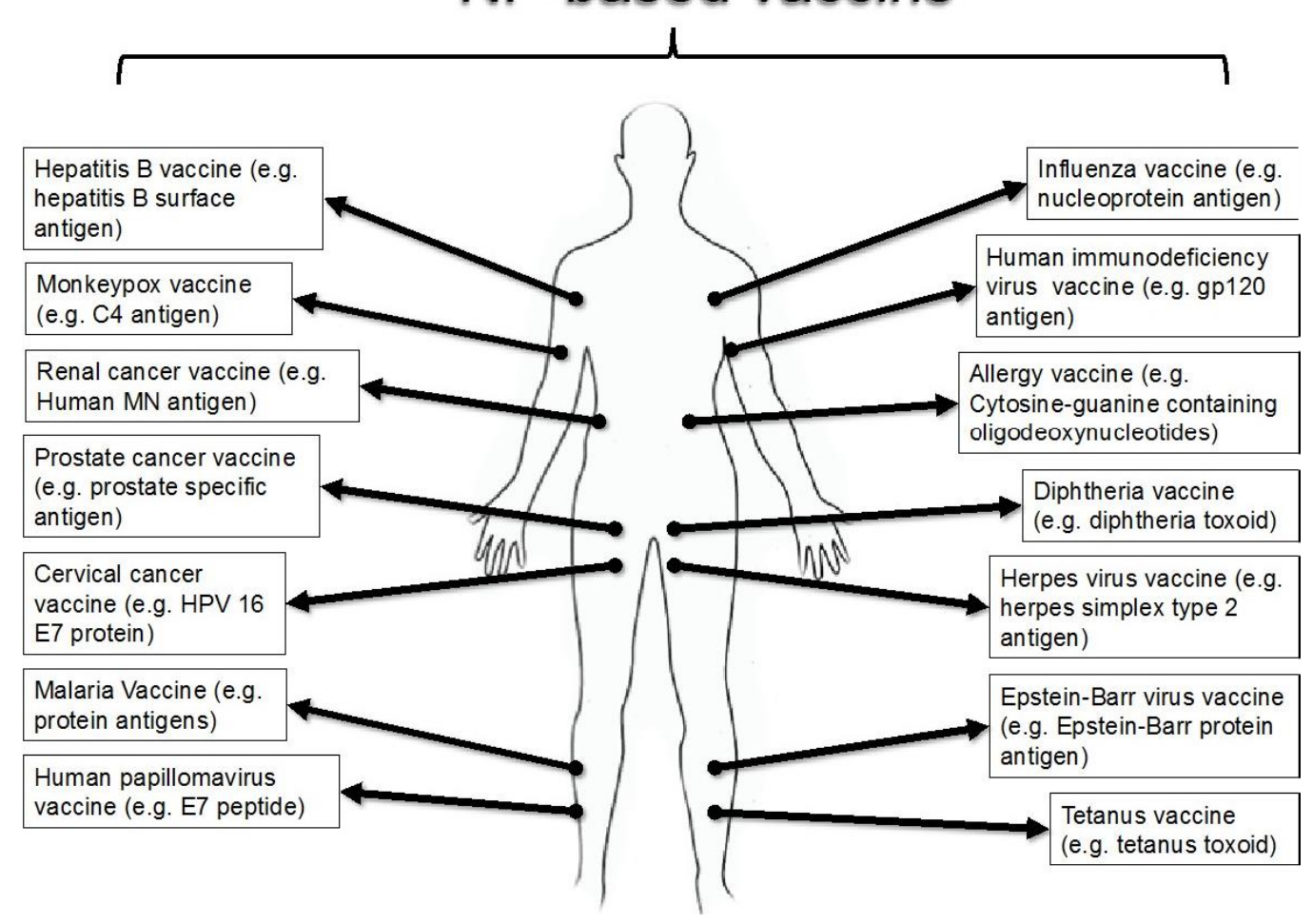

Figure 1. Overview of possible vaccines that can be generated using NPs.

Although mitochondria can serve as important modulators for vaccines by serving as unique targets, the field of mitochondria targeted vaccines by using NP delivery system is still in infancy. This might be due to limited availability of NP systems for vaccine design. In this review, we highlight recent advances of antigen delivery carriers that can be manipulated to achieve mitochondria targeting and their potential interventions as preventive/therapeutic vaccines, by categorizing them into compositional classes of: (a) polymeric; (b) liposomal; and (c) other types of antigen carrier systems. Along with discussion of mitochondria targeting moieties, examples of mitochondria targeted NP vaccines are provided as well as future directions for this field. 
Table 1. Summary of possible mitochondrial targets for vaccine development.

\begin{tabular}{|c|c|c|c|c|}
\hline Cell type & Possible targets & Immune response & Possible Application & Ref. \\
\hline Dendritic cell (DC) & $\begin{array}{l}\text { Mitochondrial DNA } \\
\text { (mtDNA) }\end{array}$ & $\begin{array}{l}\text { Induces } \mathrm{CD}^{+}, \mathrm{IFN}-\gamma, \mathrm{T} \text { cell } \\
\text { response specific for } \\
\text { tumor-associated } \\
\text { mitochondrial antigens }\end{array}$ & Cancer & [19] \\
\hline \multirow{2}{*}{$\begin{array}{l}\text { Cytolytic T } \\
\text { lymphocytes }\end{array}$} & mtDNA & $\begin{array}{c}\text { Controls the expression of } \\
\text { maternally transmitted } \\
\text { antigens }\end{array}$ & Hearing impairment & {$[23,24]$} \\
\hline & $\begin{array}{c}\text { Pyruvate } \\
\text { dehydrogenase } \\
\text { complexes }\end{array}$ & $\begin{array}{c}\text { Increases CD8+ T cells for } \\
\text { immune-pathogenesis of PBC. }\end{array}$ & $\begin{array}{l}\text { Primary biliary } \\
\text { cirrhosis }\end{array}$ & [25] \\
\hline B cells & $\begin{array}{c}\text { Mitochondrial } \\
\text { permeability transition } \\
\text { pore }(\mathrm{MPTP})\end{array}$ & $\begin{array}{l}\text { Connects the B cell antigen } \\
\text { receptor to the effector } \\
\text { caspases of apoptotic } \\
\text { cell death }\end{array}$ & acute cerebral ischemia & [26] \\
\hline $\begin{array}{l}\text { Breast cancer cell } \\
(\mathrm{MCF}-7) \text { and DCs }\end{array}$ & $\begin{array}{l}\text { Mitochondrial } \\
\text { matrix (MM) }\end{array}$ & $\begin{array}{l}\text { Generates the apoptotic cancer } \\
\text { cells providing tumor antigens } \\
\text { for immune response }\end{array}$ & Cancer & {$[21,27]$} \\
\hline $4 \mathrm{~T} 1$ cell & MM & $\begin{array}{l}\text { Increases pro-inflammatory } \\
\text { IL-2, IL-6, IL-12, TNF- } \alpha \\
\text { cytokines }\end{array}$ & Cancer & {$[28]$} \\
\hline \multirow{3}{*}{ T cells } & $\begin{array}{l}\text { Bcl-xL/Bcl-2 proteins } \\
\text { in outer mitochondrial } \\
\text { membrane }(\mathrm{OMM})\end{array}$ & $\begin{array}{l}\text { SARM causes T cell death by } \\
\text { inhibiting Bcl-xL and down } \\
\text { regulating signal-regulated } \\
\text { kinase phosphorylation for } \\
\text { immune homeostasis }\end{array}$ & Influenza & [29] \\
\hline & $\begin{array}{l}\text { 2-oxo-dehydrogenase } \\
\text { enzymes in inner } \\
\text { mitochondria } \\
\text { membrane (IMM) }\end{array}$ & $\begin{array}{l}\text { Up regulates the expression of } \\
\text { MHC class II, produces IL-2 } \\
\text { cytokine in response to } \\
\text { PDH-E2/BCKD-E2 }\end{array}$ & $\begin{array}{l}\text { Primary biliary } \\
\text { cirrhosis }\end{array}$ & {$[30]$} \\
\hline & $\begin{array}{l}\text { Electron transport } \\
\text { chain (ETC) }\end{array}$ & $\begin{array}{l}\text { Generates ROS for the nuclear } \\
\text { factor of activated T cells } \\
\text { (NFAT) and IL-2 induction }\end{array}$ & Cancer & {$[31]$} \\
\hline $\begin{array}{l}\text { Cytolytic T } \\
\text { lymphocytes }\end{array}$ & $\begin{array}{c}\text { Pyruvate } \\
\text { dehydrogenase } \\
\text { complexes }\end{array}$ & $\begin{array}{c}\text { Increases CD8+ T cells for } \\
\text { immune-pathogenesis of PBC }\end{array}$ & $\begin{array}{l}\text { Primary biliary } \\
\text { cirrhosis }\end{array}$ & [25] \\
\hline
\end{tabular}

\section{NP-based Vaccine Delivery Systems}

NP-based therapeutics are emerging as a noteworthy field in clinical research. Currently, there are several FDA approved cancer nanomedicines, such as Abraxane, Doxil, Oncaspar, etc. NPs provide an important tool for clinical application and, thus, should and can be evolved for systems that aim for various functions, such as in the case of vaccines. Adjuvant or antigen-targeting delivery systems are critical for efficient immune modulation by protecting antigens from extracellular enzymes and $\mathrm{pH}$ changes, and translocation of antigens to the target sites [32]. Here, we have categorized these NP-based vaccine delivery systems as polymeric, liposome, and others types of NP based carriers.

\subsection{Polymeric NPs as Antigen Carriers}

Antigens loaded into nanometer-sized polymeric particles were recently shown to produce good adjuvant effect [33-36]. Polymeric NPs are used as adjuvants or antigen delivery cargos that can potentially be used in mitochondria-targeted vaccines. Polymeric NP are desirable platforms due to relative ease in tailoring (i) biodegradation properties and (ii) physical properties, such as size, surface charge, and hydrophobicity, for optimum cargo delivery/circulation and mitochondrial access. A list of polymeric NP based antigen delivery systems is summarized in Table 2. 
Biodegradable NPs constructed from poly(lactic-co-glycolic acid) (PLGA) polymer are widely used as antigen carriers / adjuvants due to its biocompatible and biodegradable characteristics, with a safety profile approved by the US Food and Drug Administration (FDA) and European Medicine Agency (EMA) [37], good and controlled long-term release which results in strong immune response. Furthermore, PLGA NPs can carry a variety of antigens including gp120 and gp140 of the human immunodeficiency virus [38-40]. Not only were PLGA adjuvant NP systems reported to elicit a strong $\mathrm{T}$ cell immune response using 100 -fold lower doses $(0.05 \mu \mathrm{g})$ of $\mathrm{CpG}$ oligodeoxynucleotide antigen, NP systems also showed significantly higher cytokine secretion (up to 10-fold), as well as a comparative antibody response to normal saline delivery [41].Thus, PLGA systems may be further developed for tailored vaccines towards increasing Th1 cell and innate immune response (e.g., viral hepatitis clearance).

There are considerable challenges that must be overcome in order to develop strong PLGA-based NP systems for vaccines. For one, PLGA-based NPs have poor payload loading and display accelerated burst release of vaccines to unwanted tissue or cells. Thus, several modifications have been done to overcome these issues. For examples, a pH sensitive PLGA NPs system was developed for rapid release of ovalbumin (OVA) antigen in acidic environments to improve immune response [42]. NPs were prepared by combination methods of emulsion-diffusion-extraction and emulsification and were $\sim 890 \mathrm{~nm}$ in diameter with zeta potentials of $\sim-12 \mathrm{mV}$. The antigen release profile was $\mathrm{pH}$-dependent with over $85 \%$ release in acidic environments ( $\mathrm{pH} 5.0$ or 6.5 ) and low release $(10 \%)$ at physiological $\mathrm{pH}$ for $24 \mathrm{~h}$. In vitro studies showed that PLGA-OVA NPs significantly enhanced CD86 and CD40 co-stimulatory factors, which induced higher level of cytokines IL-1 $\beta$, IL-6, IL-12p70 and TNF- $\alpha$ than their control groups. In vivo studies of PLGA-OVA NPs demonstrated enhanced activation of B cells, $\mathrm{CD}^{+} \mathrm{T}$ cells, IgG titers, and Th1 polarization than their non-pH responsive control.

Delivery of dual or triple antigens in PLGA-NPs is also a possible strategy to enhance immune response efficiency. Co-delivery of TLR 4 ligand and TAA using PLGA-based NPs were reported to stimulate strong anti-tumor immune response [43]. This dual antigen loaded PLGA-based NP was prepared by double emulsion/solvent evaporation technique and vaccination of these NPs in healthy mice activated $\mathrm{CD} 8{ }^{+} \mathrm{T}$ cell immune responses with greater Th1 cytokines including IFN- $\gamma, \mathrm{TNF}-\alpha$, and IL-2, -6, -12 production in both lymph nodes and spleen compared to 7-acyl lipid A NPs and empty-NP immunization. Polyethylene glycol (PEG) is a flexible, biocompatible, inert, amphiphilic, and non-toxic polymer that is FDA-approved for use in human. PEG is water soluble and, in NPs, prevents interactions between NPs and the cell surface environment. However, PEG-NP's hydrophilic properties may lead to poor recognition and cellular uptake. NPs from other polymers such as poly(D,L-lactide) (PLA), poly (anhydride), poly(methyl methacrylate) (PMMA), poly(glycolic acid) (PGA), poly( $\varepsilon$-caprolactone) (PCL), chitosan, poly-L-lysine, poly( $\gamma$-glutamic acid) (PGA), can also serve as carriers for vaccine delivery.

Conjugation of two or more types of polymers by creating block copolymers, such as PLGA- $b$-PEG and PLA-b-PEG, are of particular interests as NPs carriers in vaccine development. Copolymers can be varied for ratios that to allow for the combined advantages of individual polymers and maximizes delivery and uptake efficiency. Factors including chain length of polymers, particle size, targeting moiety, and surface properties of NPs play significant roles in cellular uptake and immune efficacy of antigen. For example, Cruz et al. demonstrated significant effects of chain length of PEG and targeting moiety of antibody on the vaccine delivery and immune responses [44]. Chemically modified PLGA NPs were prepared by emulsification/solvent diffusion with various chain lengths of PEG via coupling to activated carboxyl groups. The NPs surface was coated with an antibody (hD1 or ZN-D1) identifying receptor for dendritic cells (DCs). The size of modified PLGA NPs increased with PEG chain length. The PLGA modified NPs with shorter chain length of PEG (MW: 2000-3000) and hD1 antibody showed higher uptake efficiency than longer PEG chain (MW: 6000-20000) modified larger NPs either with or without hD1 antibody. PLGA modified NPs coated with hD1 or AZN-D1 were more efficient for cellular uptake and targeting than those coated with $\mathrm{H} 200$, neck motif receptor. These results indicated 
that chain length of PEG and antibody types influence the ligand-receptor targeting by tailoring the size and surface properties of NPs. Plasmid DNA was loaded into PLGA-polyethyleneimine (PEI) NPs with positive surface charge of $40-70 \mathrm{mV}$ and size of $230-280 \mathrm{~nm}$ by precipitation-evaporation-filtration method [45]. In vitro studies showed that PLGA-PEI-DNA NPs could stimulate human DCs to secrete IL-12 and TNF- $\alpha$. In vivo study demonstrated enhanced T cell proliferation by immunization with PLGA-PEI-DNA NPs.

Biopolymers, like chitosan, can also be used to prepare comparably cost-effective NPs as stable carriers for antigens to trigger immune response for diseases, such as Hepatitis B, Tetanus, and Leishamaniasis [46-48]. For example, chitosan NPs prepared by ionic gelation were developed to successfully deliver TLR3 agonist poly (I:C) (pIC) and a T-Helper peptide (PADRE) to produce antibody against disease [49]. In vivo studies in mice indicated that both immunostimulant pIC and $T$ helper peptide were critical to reach valuable immune responses upon immunization with chitosan NPs. The present condition of antigen in the NPs was an important factor for immune responses, whereas the adsorption of peptide on the surface of NPs showed higher antibody response than the entrapping counterpart.

Table 2. Polymeric NP based antigen delivery systems.

\begin{tabular}{|c|c|c|c|c|c|}
\hline $\begin{array}{l}\text { Polymer } \\
\text { System }\end{array}$ & $\begin{array}{c}\text { Preparation/ } \\
\text { Diameter (nm) }\end{array}$ & Activity/Outcome & Delivery route & Comments & Ref. \\
\hline PLGA & $\begin{array}{l}\text { Double emulsion } \\
\text { method/320 nm }\end{array}$ & $\begin{array}{l}\text { OVA and MPLA dual loading } \\
\text { PLGA NPs show enhanced } \\
\text { mucosal immune response with } \\
\text { higher IgA titers production } \\
\text { than individually loaded NPs. }\end{array}$ & Oral & $\begin{array}{l}\text { FDA approved delivery } \\
\text { system, (OVA +MPLA) } \\
\text { PLGA NPs were stable up } \\
\text { to one month. }\end{array}$ & [50] \\
\hline PLA & $\begin{array}{c}\text { Dialysis } \\
\text { method } / 300-600 \mathrm{~nm}\end{array}$ & $\begin{array}{l}\text { HIV-1 p24 PLA NPs show the } \\
\text { best CTL results, antibody } \\
\text { production, cytokine secretion } \\
\text { (IL-2, } 4,6,10 \text {, INF- } \gamma \text { ) within } \\
\text { the controls. }\end{array}$ & $\begin{array}{l}\text { Subcutaneous } \\
\text { injection }\end{array}$ & $\begin{array}{l}\text { PLA NPs were stable } \\
\text { for months }\end{array}$ & [51] \\
\hline PGA & $\begin{array}{l}\text { Dialysis method/ } \\
200 \mathrm{~nm}\end{array}$ & $\begin{array}{l}\text { The hemagglutinin (HA) loaded } \\
\text { PGA-NPs show enhanced CTL } \\
\text { activity and greater production } \\
\text { of IFN- } \gamma \text {, IL-4, and IL- } 6 \text { in vitro. } \\
\text { NPs vaccination shows better } \\
\text { defense to influenza virus } \\
\text { infection in vivo than controls. }\end{array}$ & $\begin{array}{l}\text { Subcutaneous } \\
\text { injection }\end{array}$ & $\begin{array}{l}\text { Low cost, safe, relatively } \\
\text { abundance, water-soluble, } \\
\text { biodegradable }\end{array}$ & [52] \\
\hline PMMA & $\begin{array}{l}\text { Reflux-filtration } \\
\text { methods }\end{array}$ & $\begin{array}{l}\text { HIV-1 Tat Protein loaded } \\
\text { PMMA NPs show efficient } \\
\text { cellular uptake, well-patterned } \\
\text { antigen release properties, and } \\
\text { enhanced immune responses } \\
\text { with greater proliferation index } \\
\text { and cytokine level (INF- } \gamma \text {, IL-2) } \\
\text { compared to Tat alone. }\end{array}$ & Intramuscular & $\begin{array}{l}\text { Core-shell NPs were } \\
\text { prepared. Tat was } \\
\text { protected from oxidation. } \\
\text { No severe damage was } \\
\text { observed for Tat } \\
\text { PMMA NPs. }\end{array}$ & [53] \\
\hline PPS & $\begin{array}{l}\text { Emulsion-incubation/ } \\
\text { size was not specified }\end{array}$ & $\begin{array}{l}\text { OVA loaded PPS NPs with } \\
\text { longer peptide showed greater } \\
\text { cellular uptake, enhanced IFN- } \gamma \\
\text { secretion, and T cell activation } \\
\text { both in vitro and in vivo. }\end{array}$ & $\begin{array}{l}\text { Tail vein } \\
\text { injection }\end{array}$ & $\begin{array}{c}\text { Surfactant pluronic F127 } \\
\text { was used to stabilize NPs, } \\
\text { PPS NPs internalized into } \\
\text { cell via miscellaneous } \\
\text { pathways. }\end{array}$ & [54] \\
\hline PLA-PLGA & $\begin{array}{c}\text { Double } \\
\text { Emulsion-solvent } \\
\text { evaporation } \\
\text { method } / 450-800 \mathrm{~nm}\end{array}$ & $\begin{array}{l}\text { HBsAg co-polymeric NPs show } \\
\text { increased immune responses } \\
\text { with enhanced sIgA levels and } \\
\text { greater production of cytokines } \\
\text { (IL- } 2, \text { IFN- } \gamma \text { ) in vivo. }\end{array}$ & $\begin{array}{l}\text { Intramuscular } \\
\text { injection via } \\
\text { pulmonary } \\
\text { route }\end{array}$ & $\begin{array}{l}\text { To deliver hepatitis B } \\
\text { vaccine; Certain toxicity to } \\
\text { pulmonary epithelium still } \\
\text { exists. Limited for oral } \\
\text { vaccine delivery }\end{array}$ & [55] \\
\hline PLGA-PEG-TPP & $\begin{array}{l}\text { Nano-precipitation } \\
\text { method }\end{array}$ & $\begin{array}{l}\text { ZnPc loaded co-polymeric NPs } \\
\text { showed greatly enhanced T cell } \\
\text { activation with combination of } \\
\text { photodynamic therapy. }\end{array}$ & Ex vivo & $\begin{array}{c}\text { Copolymer is of } \\
\text { non-immunogenic and } \\
\text { nontoxic, and designed for } \\
\text { mitochondria } \\
\text { targeting delivery. }\end{array}$ & {$[21,56]$} \\
\hline
\end{tabular}


Table 2. Cont.

\begin{tabular}{|c|c|c|c|c|c|}
\hline $\begin{array}{l}\text { Polymer } \\
\text { System }\end{array}$ & $\begin{array}{c}\text { Preparation/ } \\
\text { Diameter (nm) }\end{array}$ & Activity/Outcome & Delivery route & Comments & Ref. \\
\hline PEG-PLA-PEG & $\begin{array}{c}\text { Double emulsion \& } \\
\text { solvent evaporation/ } \\
215 \mathrm{~nm}\end{array}$ & $\begin{array}{l}\text { The co-polymeric NPs showed } \\
\text { elevated immune response } \\
\text { in vivo. Cytokine levels (IFN- } \gamma \\
\text { and IL-2) were } \\
\text { greatly enhanced. }\end{array}$ & Oral & $\begin{array}{l}\text { The NPs was stable in } \\
\text { gastric and intestinal } \\
\text { fluids. } 90 \% \text { of hepatitis B } \\
\text { antigen was encapsulated. }\end{array}$ & [57] \\
\hline PCL-PEG-PCL & $\begin{array}{l}\text { Emulsion-solvent } \\
\text { evaporation } \\
\text { method/137 nm }\end{array}$ & $\begin{array}{l}\text { The co-polymeric NPs delivery } \\
\text { of bFGF antigen induces better } \\
\text { antibody production for } \\
\text { immune response in vivo than } \\
\text { antigen alone. }\end{array}$ & $\begin{array}{l}\text { Subcutaneous } \\
\text { injection }\end{array}$ & $\begin{array}{l}\text { A few studies have } \\
\text { been made on this } \\
\text { co-polymeric system. }\end{array}$ & [58] \\
\hline Chitosan & $\begin{array}{l}\text { Ionotropic gelation } \\
\text { technique/160-200 nm }\end{array}$ & $\begin{array}{l}\text { rHBsAg loaded chitosan NPs } \\
\text { induced pretty delay immune } \\
\text { response but much greater } \\
\text { production of IgG than } \\
\text { conventional alum vaccines } \\
\text { in vivo. }\end{array}$ & $\begin{array}{l}\text { Intramuscular } \\
\text { or intranasal }\end{array}$ & $\begin{array}{l}\text { NPs could be damaged by } \\
\text { centrifugation-resuspension } \\
\text { cycles. NPs could release } \\
\text { antigen in } \\
\text { a well-controlled pattern. }\end{array}$ & [46] \\
\hline Chitoson-PLGA & $\begin{array}{l}\text { Emulsification-solvent } \\
\text { extraction/448 nm }\end{array}$ & $\begin{array}{l}\text { Chitoson/PLGA NPs show } \\
\text { gradual release of OVA up to } \\
100 \% \text { in } 15 \text { days, effective } \\
\text { cellular uptake by crossing nasal } \\
\text { epithelium, efficient T cell } \\
\text { proliferation and stimulation } \\
\text { in vivo. }\end{array}$ & Nasal & $\begin{array}{l}\text { NPs charge, size, and } \\
\text { antige release properties } \\
\text { are critical factors } \\
\text { for vaccination. }\end{array}$ & [59] \\
\hline
\end{tabular}

\subsection{Liposomal Systems as Antigen Carrier/Adjuvant}

Liposomes are effective antigen carriers due to biodegradable, nontoxic, non-immunogenic, and antigen loading properties. These systems are reported to deliver a wide range of antigens, such as E7 peptide and HSP70, which can potentially vaccinate against many disease, such as cancer and human papilloma virus [14,60]. Table 3 summarizes the liposome-based NPs in vaccine delivery systems. Lipids, such as dioleoyl phosphatidyl ethanolamine (DOPE), dioleoyl phosphatidylcholine (DOPC) cholesterol, dioleoyldimethylammonium chloride (DODAC), dioleoyldimethylaminopropane (DOTAP), dipalmitoylphospatidylcholine (DPPC), dipalmitoylphospatidylglycerol (DPPG), can be used to prepare liposome-based NP delivery systems for vaccines. The endosomolytic lipid DOPE can enhance the efficacy of vaccine delivery by endosomal escape through membrane disruption and fusion processes [61]. For instance, Cui et al. [62] reported DOPE as lipid source for preparation of liposome-based adjuvant NPs as plasmid DNA (pDNA) vaccine carriers. The pDNA-lipid adjuvant NPs had a 250-fold enhanced activity than pDNA alone for in vivo immunization in BALB/c mice model.

Liposomal NPs are potentially able to cross epithelial barriers and protect encapsulated antigens from enzymatic attack in physiological environment [63]. Oral route delivery of vaccine is one of the most challenging and difficult tasks in vaccine development. Towards the development of oral or nasal vaccines, liposomal NPs can undergo reverse denaturation, surviving GI tract and other enzyme-rich environments. However, liposomal NPs are unstable and rapidly cleared by the mononuclear phagocyte system (MPS). The combination of liposome and polymer is a possible strategy for construction of antigen nanovesicles to resolve deficiencies in uptake efficacy and immune response enhancement. Many types of combination nanocarriers, such as liposome-chitosan NPs [64], were reported for drug-delivery and such systems may be further evolved for antigen delivery as well. Polymerized liposomes, which can be prepared under mild conditions comparable to conventional liposomes, exhibit greater encapsulation efficiency, better activity of antigen, and more controllable antigen release profile than conventional liposomes. The solid and stable structure of polymerized liposomes with easy preparation method make these NPs a promising antigen delivery vesicle [65]. 
Polymerized liposomes showed their potential as oral vaccine delivery system [66], however, further studies are required for clinical application.

Solid Lipid NPs (SLNPs) with a diameter of 50-1000 $\mathrm{nm}$ can be prepared by replacing the liquid lipid by various types of solid lipids, such as fatty acids, triglycerides, and their combinations [67]. The uptake efficiency and immunogenicity of antigen loaded SLNPs can be affected by size, lipid source, preparation method, and surface properties. For example, Bhargava et al. reported SLNPs as tumor antigen carriers, which demonstrated immune signal induction with no toxicity [68]. With tumor lysate as antigen, SLNPs were synthesized by solvent injection method with tristearin as a lipid source. SLNPs size was controlled by varying preparation parameters. The monomannosyl-dioleyl glycerol modified SLNPs showed the highest uptake efficiency and immune response among other lipid modified controls, which may be attributed to efficient antigen capture by mannose receptors of DCs.

The efficacious delivery and safety profile of liposome-based NP systems make them as promising vehicles for vaccine delivery. The immune-stimulant sipuleucel-T received FDA approval for asymptomatic or minimally symptomatic prostate cancer in 2010 and is used to prime metastatic prostate cancer patient's T-cells to target the patient's own cancer cells. Liposomes formulated prostate-specific antigen (PSA) is reported to generate immune response when injected into patients (65-80 years old) with prostate cancer. Out of 10, 8 patients showed PSA-reactive T-cell frequencies using in vitro sensitization method. The vaccination trial indicated that the patients survived within 22-33 months with one still alive during the testing timeline, whereas eight patients were stable and the rest of them deteriorated to progressive disease [69]. Another pilot study demonstrated the safety profile of MUC1 BLP25 liposomal vaccine. L-BLP25 was prepared by encapsulating BLP25 lipopeptide to form liposomal adjuvant with monophosphoryl lipid A and 3 lipids (cholesterol, dimyristoyl phosphatidylglycerol and dipalmitoyl phosphatidylcholine). Twenty patients ( $\geqslant 18$-year-old) were continuously vaccinated with BLP25 liposome vaccine after single dose of cyclophosphamide for up to 1 year. No autoimmunity was observed, indicating that L-BLP25 vaccine is safe for therapeutic use [70]. A recent internationally randomized and double-blind phase III clinical trial composed of 1513 patients with non-small-cell unresectable stage III lung cancer, tested L-BLP25 as an immunotherapeutic [71]. The overall survival was 25.6 months for patients vaccinated with L-BLP25 compared to 22.3 months for patients treated with placebo. These results indicate the potential clinical benefit of L-BLP25 for cancer immunotherapy and warrant further studies [71].

\subsection{Others Types of NP-based Systems as Antigen Carrier/Adjuvant}

There are reports on other NP carriers for the delivery of vaccines other than polymeric or liposome-based NPs. For instance, inorganic NPs are suitable antigen delivery systems due to wide availability, rich functionality, and good biocompatibility. Many inorganic materials, such as aluminum salt, silver, gold, carbon materials, silicon oxide, and iron oxide were studied for use as antigen delivery carriers. Table 4 summarizes these NP carriers for antigen delivery. For example, Villa et al. [72] reported single-wall carbon nanotubes (SWNTs) as human tumor antigens carriers to improve immune responses. SWNT-peptide delivery systems were constructed using weakly immunogenic cancer-associated peptide WT1-Pep427 consisting of 19 amino acids. The SWNT-peptide delivery systems showed enhanced in vivo immune responses in mice model. More importantly, SWNTs alone did not show any toxicity or immunogenicity in vitro or in vivo, and no immunogenic responses were reported for this SWNT construct.

Layered double hydroxides NPs (LDH-NPs) are considered as potential vaccine nanocarriers due to good biocompatibility, low toxicity, great antigen protective and controllable release properties. LDH-NPs are hydrotalcite-like anionic clays with a common formula as $\left[\mathrm{M}^{2+}{ }_{1-\mathrm{x}} \mathrm{M}^{3+}{ }_{\mathrm{x}}(\mathrm{OH})_{2}\right]^{\mathrm{x}+}\left(\mathrm{A}^{\mathrm{n}-}\right)_{\mathrm{x} / \mathrm{n}} \cdot \mathrm{yH}_{2} \mathrm{O}$, where $\mathrm{M}$ is a metal cation (e.g., $\mathrm{Mg}^{2+}, \mathrm{Al}^{3+}$ ) located at octahedral sites and $\mathrm{A}$ is a inorganic anion (e.g., $\mathrm{Cl}^{-}, \mathrm{CO}_{3}{ }^{2-}$ ) situated at interlayers [73]. LDH-NPs provides efficient uptake of antigens due to their high endosomal buffering capacity and controllable released profiles [74]. Yan et al. demonstrated that OVA loaded LDH-NPs $(\sim 100 \mathrm{~nm}$ in diameter) prepared by a combination of precipitation 
and hydrothermal methods exhibited less inflammation but comparable adjuvanticity to induce Th1/Th2 immune response [75]. Modification of OVA-LDH-NPs by CpG receptor ligand significantly enhanced immune response. In vivo studies showed that LDH-CpG-OVA NP injections had six-fold of IgG2a/IgG1 ratio and less inflammatory activity than mice treated with Alum-CpG-OVA. Hybrid of different types of NPs to combine the advantages of individual NPs is an effective strategy to enhance vaccine immune response. This hybrid strategy is widely used in drug delivery, and can also be applied to vaccine developments. For example Wang et al. reported $\mathrm{SiO}_{2} @ \mathrm{LDH}$ NPs as adjuvant for DNA vaccination to improve immune response for hepatitis B [76]. Core-shell $\mathrm{SiO}_{2} @ \mathrm{LDH}(\sim 210 \mathrm{~nm}$ in diameter) NPs showed adjuvant activity for maturation of DC in vitro and enhanced immune responses with greater generation of IFN- $\gamma$, IL-6, MHCII, and CD86 in vivo. However, toxicity of LDH NPs needs to be addressed for clinical applications.

Table 3. A summary of liposome-based antigen delivery systems.

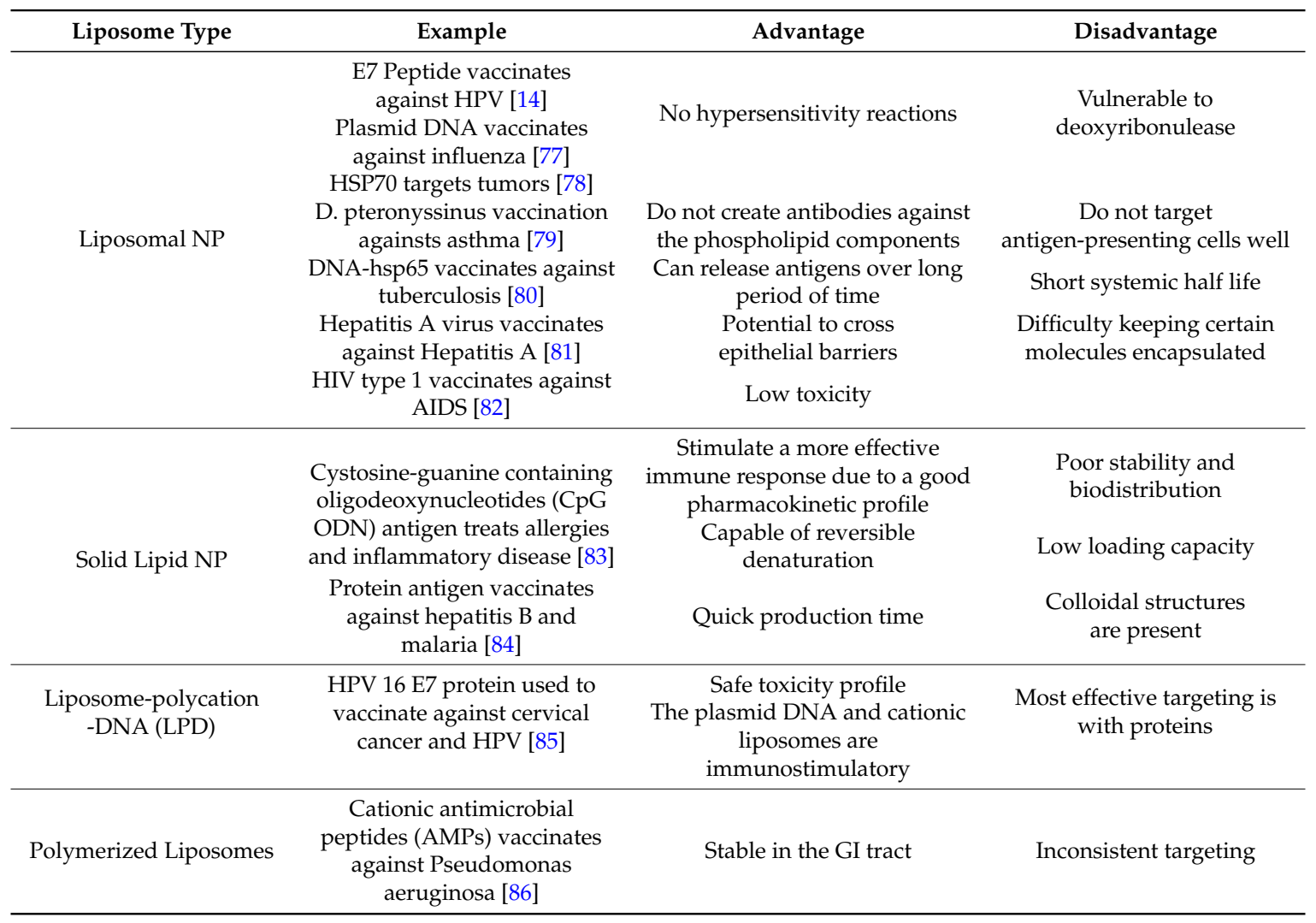


Table 4. Summary of other NPs-based antigen delivery systems.

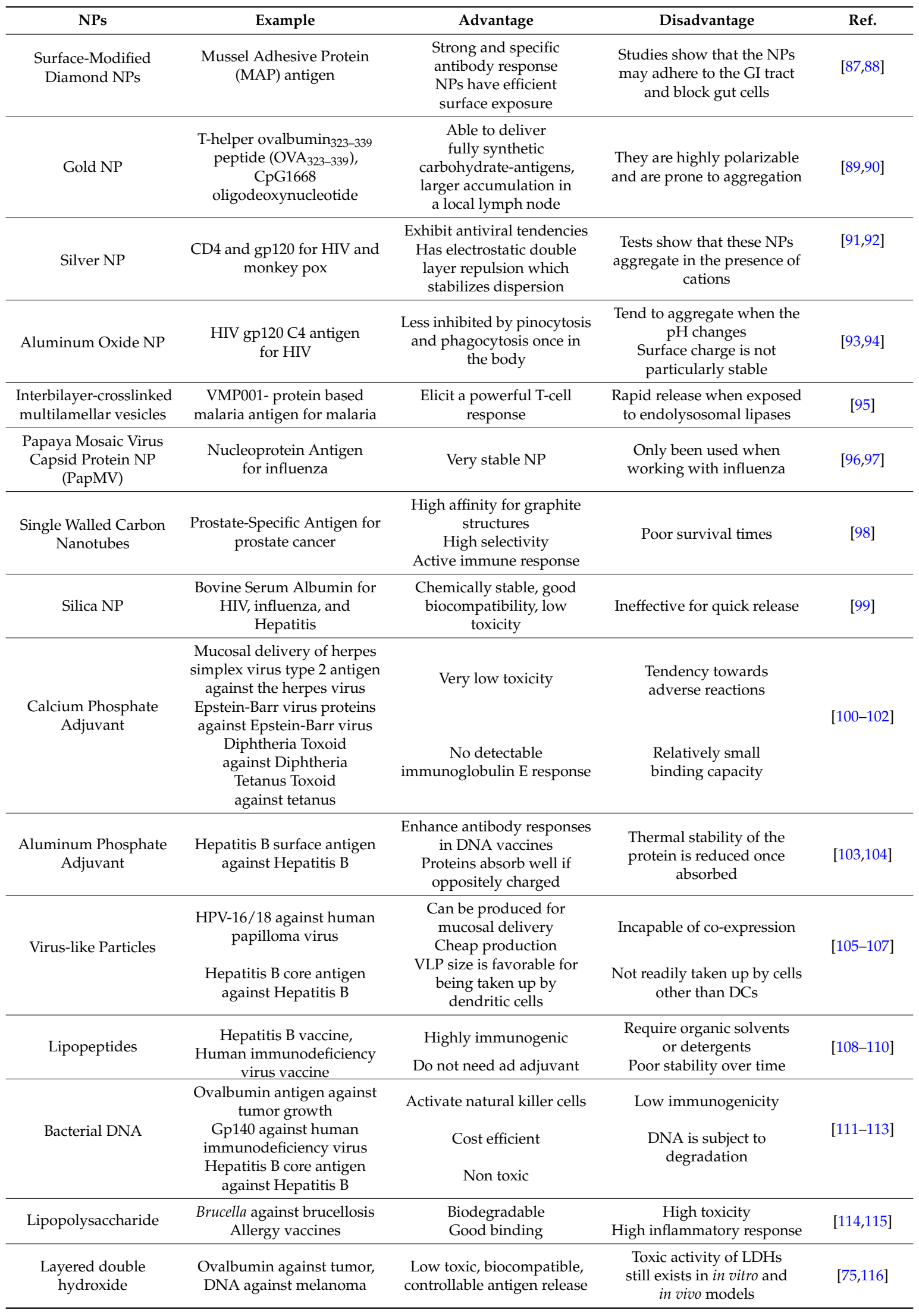




\section{Mitochondria Targeting Moiety}

As mentioned previously, mitochondria have unique immunostimulatory capabilities that can enhance vaccine activity. Mitochondria targeting can be achieved by selectively conjugating the polymer or modifying the particle surface with a mitochondria targeting moiety. The unique properties of the mitochondrion, such as the existence of a mitochondrial membrane potential $\left(\Delta \psi_{\mathrm{m}}\right)$ across a mitochondrion's double membrane, and the mitochondrial protein import machinery indicates that lipophilic cations and specific mitochondrial targeting sequences (MTS) can be used to achieve effective mitochondria targeting.

(i) Lipophilic cation: One approach to confer mitochondria targeting properties to a vaccine is through conjugation to a delocalized lipophilic cation, such as triphenylphosphonium (TPP) cation [28,56,117], rhodamine 123 [118], or methyltriphenylphosphonium (TPMP) cation [119]. Lipophilic cations access the mitochondrion through a driving force caused by the $\Delta \psi_{\mathrm{m}}$ gradient [120]. Cancer cells display a hyperpolarized $\Delta \psi_{\mathrm{m}}$ across membranes in their mitochondrial population, which facilitate the accumulation of lipophilic cations. Thus, lipophilic cation conjugated NPs can be used as carriers to target the antigens to mitochondria. A summary of mitochondria targeting moieties is shown in Table 5.

Table 5. Summary of the lipophilic cations as mitochondria targeting moiety.

\begin{tabular}{|c|c|c|c|}
\hline Targeting moiety & Examples & Outcome & Ref. \\
\hline $\begin{array}{l}\text { Phospholipid } \\
\text { (PL)-PEG-NH }\end{array}$ & $\begin{array}{l}\text { Single walled carbon } \\
\text { nanotube } \\
\text { functionalization } \\
\text { (SWNT-PL-PEG) }\end{array}$ & $\begin{array}{l}\text { To reduce nonspecific binding effect of } \\
\text { SWNT surface. To improve the } \\
\text { solubility of SWNTs in aqueous } \\
\text { solutions. To accumulate in the } \\
\text { mitochondria of normal and cancer cells }\end{array}$ & [121] \\
\hline $\mathrm{TPP}^{+}$ & $\begin{array}{l}\text { PLGA-PEG-TPP as } \\
\text { carrier for } \mathrm{ZnPc}\end{array}$ & $\begin{array}{l}\text { To induce cytotoxicity in cancer cells } \\
\text { under light irradiation, which is used to } \\
\text { activate DCs }\end{array}$ & [21] \\
\hline Rhodamine 123 & $\begin{array}{l}\text { Liposomes-rhodamine- } \\
\text { 123-conjugated polymer }\end{array}$ & $\begin{array}{l}\text { Least toxic among the liphophilic dye } \\
\text { Facilitate the cellular association and } \\
\text { internalization, direct the trafficking of } \\
\text { NPs to mitochondria, and substantial } \\
\text { cell killing was observed as the } \\
\text { drug cargo }\end{array}$ & {$[118,122]$} \\
\hline $\begin{array}{l}\text { Methyltriphenyl } \\
\text { phosphonium }\end{array}$ & NA & $\begin{array}{l}\text { Did not protect against cell death. } \\
\Delta \psi_{\mathrm{m}} \text { was selectively depolarized }\end{array}$ & {$[119,123]$} \\
\hline Dequalinium (DQA) & $\begin{array}{l}\text { DQA-PEG(5000)-DSPE } \\
\text { DQA-PEG(2000)-DSPE) }\end{array}$ & $\begin{array}{l}\text { To cause cell death by inhibiting the } \\
\text { mtDNA synthesis }\end{array}$ & [124-126] \\
\hline MKT-007 & NA & $\begin{array}{l}\text { A mitochondria localized cationic dye, } \\
\text { causes selective death of cancer cells }\end{array}$ & [127] \\
\hline F16 & $\begin{array}{l}\text { F16 conjugated with } \\
\text { 5-fluorouracil }\end{array}$ & $\begin{array}{c}\text { F16 was used as a vehicle, selectively } \\
\text { inhibits tumor cell proliferation and } \\
\text { dissipates } \Delta \psi_{\mathrm{m}}\end{array}$ & {$[128,129]$} \\
\hline $\begin{array}{l}\text { N-Heterocyclic } \\
\text { Carbene (NHC) }\end{array}$ & Gold(I)-NHC Complex & $\begin{array}{l}\mathrm{Au}(\mathrm{I})-\mathrm{NHC} \text { complexes toxic to breast } \\
\text { cancer cell (MDA-MB-231, } \\
\text { MDA-MB-468), but not to normal cells }\end{array}$ & [130] \\
\hline
\end{tabular}

TPP is a commonly used cation for mitochondria targeting due to its characteristic facile conjugation and efficient rapid uptake into mitochondrion. Nevertheless, the toxicity of TPP-based small organic molecules limits its use in therapeutic applications. Conjugation of TPP cations into a stable polymer, lipid or other nanomaterials can solve this problem. TPP derived polymers used as mitochondria targeting moiety for polymer surface manipulation as delivery systems exhibited 
less toxicity in recent studies. We recently reported a biocompatible polymeric NP for mitochondria targeting, where biodegradable PLGA- $b$-PEG was functionalized with a terminal TPP cation, forming PLGA-PEG-TPP [56,131]. This polymer has the advantages of being non-toxic, easy to prepare, and stable. Furthermore, it demonstrated success in efficient mitochondria associated delivery of different small molecules which included Pt(IV) compounds [132-134], ZnPc [21,27], aspirin [135]. Tagging to other nanomaterials with TPP cation is widely used and achieved by our group. For instance, gold nanoparticle (AuNP) to 3-bromopyruvate, high density lipoproteins [136,137], and all display no differences between controls and TPP conjugated NPs in toxicity and immunogenicity evaluations. Hence, these TPP-modified NP systems are promising for antigen delivery to mitochondria as well.

(ii) Mitochondria targeting sequence (MTS): Mitochondrial proteins are encoded by nuclear gene and further synthesized by cytoplasmic free ribosomes [138]. The translocation and intracellular sorting of these proteins to mitochondrial compartments depend on MTS [139]. Thus, MTS can be used as the targeting moiety. MTS commonly have a length of 20-40 amino acids and are located at the amino terminal of the precursor proteins. MTS form amphiphilic $\alpha$-helical conformations with cationic amino acids on one side and hydrophobic amino acid on the opposing surface [140-142]. Table 6 summarizes MTS as mitochondria targeting ligands and their targets in the protein import machinery pathway.

Table 6. Summary of peptides with a mitochondria targeting sequence.

\begin{tabular}{|c|c|c|c|c|}
\hline Name & Sequence & Targets & Comments & Ref. \\
\hline $\begin{array}{l}\text { Mitochondrial alanine } \\
\text { aminotransferase } \\
(\mathrm{mALT})\end{array}$ & $\begin{array}{c}\text { MSATRMQLLSPRNVRLLSRGRSE } \\
\text { LFAGGSGGGPRVRSLISPPLSSSS } \\
\text { PGRALSSVSATRRGLPKEK } \\
\text { MTENGVSSRAKVLTIDT }\end{array}$ & $\begin{array}{l}\text { Through interaction with } \\
\text { translocases of the outer and } \\
\text { inner mitochondrial } \\
\text { membranes }\end{array}$ & $\begin{array}{l}\text { Exhibits higher affinity } \\
\text { for L-alanine } \\
\text { Amino acids 1-83 } \\
\text { contains MTS }\end{array}$ & [143] \\
\hline $\begin{array}{l}\text { MTS-ExoIII-TAT } \\
\text {-fusion protein }\end{array}$ & MLSRAVCGTSRQLAPALGYLGSRQ & Mitochondrial matrix & $\begin{array}{l}\text { More efficient in mtDNA } \\
\text { damage and less repair to } \\
\text { cancer cell }\end{array}$ & {$[144]$} \\
\hline p53 Protein & $\begin{array}{c}\text { MLFNLRILLNNAAFRNGHN } \\
\text { FMVRNFRCGQPLQ }\end{array}$ & $\begin{array}{l}\text { Localizes within the } \\
\text { membrane compartment }\end{array}$ & $\begin{array}{l}\text { Mitochondrial accumulation } \\
\text { of p53 is rapid, and precedes } \\
\text { the apoptotic cascade. }\end{array}$ & [146] \\
\hline XJB-5-131 & $\begin{array}{l}\text { 4-hydroxy-2,2,6,6-tetramethyl } \\
\text { piperidine-1-oxyl conjugated to } \\
\text { nitroxide-Leu-D-Phe-Pro-Val-Orn }\end{array}$ & Mitochondrial membrane & ROS/RNS scavenger & [149] \\
\hline Gramicidin S & Boc-Leu- ${ }^{D}$ Phe-Val-Orn(Cbz)-OMe & Mitochondrial membrane & Electron scavenger & [150] \\
\hline $\begin{array}{l}\text { Nitroxide/ } \\
\text { Hemigramicidin S } \\
\text { Conjugate }\end{array}$ & $\begin{array}{c}\text { Hemigramicidin } \\
\text { S-4-amino-2,2,6,6-tetramethyl } \\
\text {-piperidine-N-oxyl } \\
\text { (hemi-GS-TEMPO) 5-125 }\end{array}$ & $\begin{array}{l}\text { Accumulates at the interface } \\
\text { of mitochondrial membrane }\end{array}$ & $\begin{array}{l}\text { Acts as electron scavenger } \\
\text { and provides the } \\
\text { radioprotection of gamma }\end{array}$ & [151] \\
\hline $\mathrm{COX1}_{291-306}$ & MFTVGLDVDTRTYFT & mtDNA & $\begin{array}{l}\text { Stimulates the } \mathrm{CD} 8^{+} \text {IFN- } \gamma^{+} \\
\text {T cell response specific for } \\
\text { tumor-associated } \\
\text { mitochondrial Ags }\end{array}$ & [19] \\
\hline KLA peptide & $\mathrm{D}(\mathrm{KLAKLAK})_{2}$ & Mitochondrial membrane & $\begin{array}{l}\text { KLA lysine units interact } \\
\text { with the membranes for } \\
\text { mitochondria uptake via } \\
\text { hydrogen bonding and } \\
\text { electrostatic attraction }\end{array}$ & [154] \\
\hline
\end{tabular}


Table 6. Cont.

\begin{tabular}{|c|c|c|c|c|}
\hline Name & Sequence & Targets & Comments & Ref. \\
\hline RLA peptide & ${ }_{\mathrm{D}}\left[\mathrm{RLARLAR}_{2}\right.$ & $\begin{array}{l}\text { Mitochondrial outer } \\
\text { membrane }\end{array}$ & $\begin{array}{l}\text { The substitution of D-lysines } \\
\text { in KLA with D-arginines } \\
\text { improves the plasma } \\
\text { membrane permeability and } \\
\text { increases mitochondrial } \\
\text { accumulation of RLA (as } \\
\text { early as } 6 \text { min) }\end{array}$ & [155] \\
\hline $\begin{array}{l}\text { Mitochondrial open } \\
\text { reading frame of the } \\
\text { 12S rRNA-c (MOTS-c) }\end{array}$ & MRWQEMGYIFYPRKLR & mtDNA & $\begin{array}{c}\text { 16-amino-acid peptide, } \\
\text { which promotes metabolic } \\
\text { homeostasis and prevents } \\
\text { the obesity and insulin } \\
\text { resistance }\end{array}$ & [156] \\
\hline Y- or M-conjugate & $\begin{array}{c}\mathrm{NH}_{2} \text {-MLSLRQSIRFFKPAT-o-o- } \\
\text { N-TTCCTCGCTCACT-c (Y } \\
\text { conjugate) } \\
\text { NH-MALLRGVFIVAAKRTPF-o-o- } \\
\text { N-GATTCTTCACCGT-C } \\
\text { (M-conjugate) }\end{array}$ & Matrix & $\begin{array}{l}\text { Accesses into the matrix } \\
\text { through outer and inner } \\
\text { mitochondria protein import } \\
\text { channels }\end{array}$ & [157] \\
\hline $\begin{array}{l}\text { Mitochondria- } \\
\text { penetrating peptides } \\
\text { (MPPs) }\end{array}$ & 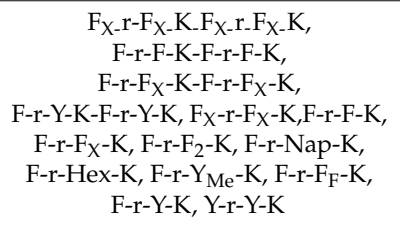 & Matrix & $\begin{array}{l}\text { Systematic series of MPPs } \\
\text { were studied, delivery of } \\
\text { nonpolar species into } \\
\text { mitochondria has been } \\
\text { demonstrated to be } \\
\text { successful }\end{array}$ & [158] \\
\hline MTS-Cys peptide & $\begin{array}{c}\mathrm{NH}_{2} \text {-MVSGSSGLAAARLLSR } \\
\text { TFLLQQNGIRHGSYC }\end{array}$ & $\begin{array}{l}\text { Mitochondrial outer } \\
\text { membrane }\end{array}$ & $\begin{array}{l}\text { MTS peptide can be } \\
\text { enhanced slightly outer } \\
\text { stearyl-R8 modification }\end{array}$ & {$[159,160]$} \\
\hline
\end{tabular}

\section{Examples of Targeted NP-Based Vaccine}

To demonstrate how mitochondria targeting NP-based vaccines can be developed, here we will provide possible modifications for immune modulation and vaccine development.

$\mathrm{T}$ lymphocytes with CD4 and CD8 surface proteins are referred to as $\mathrm{CD} 4^{+}$and $\mathrm{CD} 8^{+} \mathrm{T}$ cells, respectively. $\mathrm{CD} 8^{+} \mathrm{T}$ cells are cytotoxic when activated within the immune system, whereas $\mathrm{CD} 4^{+}$ $\mathrm{T}$ cells are helpers in activating $\mathrm{CD} 8^{+} \mathrm{T}$ cells or humoral immune responses [161]. The activation of $\mathrm{CD} 8^{+} \mathrm{T}$ cells requires the presence of APCs. DCs, the most effective APCs, present antigens to $\mathrm{B}$ and $\mathrm{T}$ lymphocytes for initiating antigen-specific immune responses or immunological tolerance through antigen and costimulatory molecules [162,163]. T-cell antigen receptors recognize antigens by binding APC surface major histocompatibility complex (MHC) molecules, whereas CD8 ${ }^{+} \mathrm{T}$ cells are activated by DCs $[164,165]$. Thus, DCs are attractive for therapeutics that rely on immune mediation, such as vaccines, and can be used to target infection, cancer, and tumor immunity [165-167].

DCs play an important in role in shaping adaptive immune responses. When activated, immature DCs express increased levels of co-stimulatory molecules, consequently leading to potent adaptive immune response [168]. Activation of DCs occurs in response to inflammatory chemokines, such as MCP1, MI- $3 \alpha$. DCs are recruited to the inflammation site, where they mature into functional DCs to regulate antigen capturing, processing, and expression of co-stimulatory molecules for activating T cells $[165,169,170]$. Because DCs are the primary APCs and their activation and maturation is crucial in shaping an effective T-cell response against invading pathogens or cancer cells, approaches aimed to increase uptake, activation and efficiency in antigen presentation should improve vaccine efficacy. In this way, NP-based antigen delivery systems can be used to drive immature DCs towards maturation for immune response activation against a delivered antigen.

Chong et al. [38] reported PLGA NPs for co-delivery of hepatitis B core antigen (HBcAg) and monophospholipid A (MPLA), a ligand for TLR, as therapeutic vaccines. A PLGA NP system was used to deliver antigen and Th1 promoting adjuvant to DCs to enhance immune response. The study demonstrated a synergistic effect, in regards to the PLGA NP co-delivery system, with anti-HBcAg IgG detection in sera and robust $\mathrm{T}$ cell proliferation response in mice via a booster dose. IFN- $\gamma$ produced 
by $\mathrm{T}$ cells from the spleen and lymph nodes were 4- and 6-fold enhanced in mice immunized with HBcAg + MPLA-NPs than HBcAg NPs, respectively. Furthermore, no IL-4, a cytokine associated with cytotoxic immune response dampening, was found. Pulsing synthetic tumor peptides to DCs was demonstrated to elicit protective and therapeutic antitumor immunity [171]. A mitochondria targeting NP vaccine can be achieved by modifying this PLGA-NP carrier with a mitochondria targeting ligand, such as TPP.

A mechanism in which a vaccine can confer immune protection against disease using APCs is through triggering the selective or abundant expression or release of internal antigen in dysfunctional cells. Apoptotic cells, tumor lysates, and TAAs are all types of internal antigens that can be recognized by APCs. Rahma et al. [172] reported that pre-immature DCs pulsed with HPV16 E6 or E7 peptide derived from early genes E6 and E7 in high-risk HPV types 16 and 18 were well tolerated and able to induce specific immune responses in patients for therapeutic cervical cancer. Other vaccines are being developed against TAAs for vaccination of patients with various cancers. Rong et al. [173] developed a DC-based vaccine using MUC1-peptide, a TAA associated with late stage pancreatic cancer. In preliminary studies, IFN- $\gamma$ and granzyme B, markers for cytotoxic immune response, were significantly enhanced in some patients. Phuphanich et al. [174] demonstrated the feasibility, safety, and bioactivity of TAA peptide for autologous vaccines by pulsing a class 1 peptide TAA expressed in patient's glioma onto DCs. The TAA peptide pulsed DC vaccine administered intradermally into patients was nontoxic and led to elimination of $\mathrm{CD}_{133^{+}}$recurrent tumors cells. It is possible to target mitochondria of dysfunctional cells using NP-based system to trigger increased expression of internal antigens, especially TAAs, by inducing apoptosis (and generating apoptotic cells) for APC recognition and vaccines.

Antigen simulating activity by adjuvant has potential for synergistic effects resulting in stronger immune responses compared to antigen or delivery system alone. Tamayo et al. [175] reported a poly(anhydride) NP system for Th1 adjuvant immunoprophylaxis and immunotherapy. Studies demonstrated that poly(anhydride) NPs can act as agonists of various TLRs (e.g., TLR2, -4, and -5), to induce Th1-cytokine production (IFN- $\gamma$, IL-12) and trigger the expression of CD54 and CD86 co-stimulatory molecules after incubation with DCs. The in vivo studies suggested that NPs help elicit $\mathrm{CD}^{+} \mathrm{T}$ cell response. The co-administration of empty NPs with OVA showed induction of cytotoxic T cells specific for target cells. Furthermore, IFN- $\gamma$ was detected in splenocytes from mice immunized with NPs and OVA. Aluminum-based adjuvants are licensed in vaccine with long record of safety without side effects of immune complex disorders [176]. $\alpha-\mathrm{Al}_{2} \mathrm{O}_{3} \mathrm{NPs}$ is reported to be a promising adjuvant in therapeutic cancer vaccines [177]. In vitro and in vivo studies demonstrated that the required antigen necessary to activate $\mathrm{T}$ cells was reduced by using $\alpha-\mathrm{Al}_{2} \mathrm{O}_{3} \mathrm{NP}$ adjuvant system. Notably, tumor growth was inhibited for more than 40 days and high levels of OVA-specific T cells were detected in mice immunized by $\alpha-\mathrm{Al}_{2} \mathrm{O}_{3}$-OVA NPs.

Photodynamic therapy (PDT) is a rapidly developing tactic for therapeutic vaccines. It has the advantage of accurately locating photosensitizer (PS) to the desired sites by light irradiation [178]. PS molecule can be excited to produce reactive oxygen species (ROS) $[179,180]$. The increase in ROS results in tumor cell apoptosis and stimulates the host's immune response. A combination of PDT with mitochondria targeted NP is a possible strategy to stimulate the immune system. Our group [21] reported mitochondria targeted NPs containing ZnPc and combined with PDT to ex vivo stimulate DCs to secrete the cytokines, especially IFN- $\gamma$ and DC mediated activation of CD8 ${ }^{+} \mathrm{T}$ cells by procuring antigens from MCF-7 breast cancer cells (Figure 2). The mitochondria-targeted polymer PLGA- $b$-PEG-TPP was employed as ZnPc delivery cargo with TPP cation as mitochondria targeting moiety. The targeted ZnPc NPs showed enhanced apoptotic properties compared to non-targeted NPs by triggering mitochondria-mediated apoptosis. The TAAs from apoptotic cancer cells were then released and internalized by DCs, which further led to the CD8 ${ }^{+}$T cell activation. Cytokines IL-18 and IFN- $\gamma$ were secreted by bone marrow derived DCs stimulated by apoptotic cancer cells produced by mitochondria targeted $\mathrm{ZnPc} \mathrm{NP}$ treatment in the presence of light. 


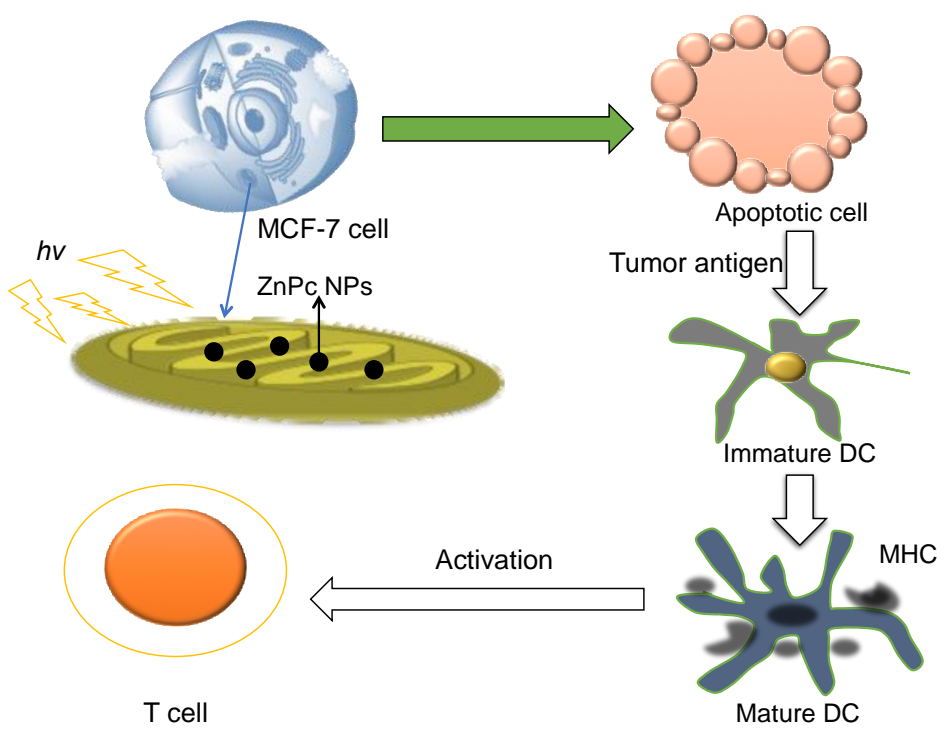

Figure 2. The schematic diagram of action of mitochondria targeted ZnPc NPs. Redrawn from Reference [21].

These results indicated that mitochondria-targeted-NP delivery systems containing mitochondria-acting photosensitizers are suitable for activating tumor cells which can further activate DCs for subsequent immune response. Our group also reported the combination of $\mathrm{ZnPc}$ and CpG-ODN in PLGA- $b$-PEG polymer carrier, which resulted in significant phototoxicity of 4T1 metastatic mouse breast carcinoma cells [28]. The PLGA-b-PEG-NP system was modified with CpG-ODN-coated gold NPs on the surface. The CpG-ODN-Au-ZnPc-Poly-NPs were highly toxic to $4 \mathrm{~T} 1$ cells under irradiation [28]. These results suggest that patients with light accessible cancers may be treated by administration of a PDT active mitochondrial targeting vaccine NP systems that capitalize on optimizing immune function for cancer cell death and prevention, overall preventing the need for harsh chemotherapeutics and decreasing the rate of recurrence via lingering immune surveillance by memory cells.

Besides DCs, microfold cells (M cells), specific epithelial cells of mucosa-related lymphoid tissues that transport antigens from the lumen to immune cells, and macrophages can also initiate immune response and/or tolerance. Thus, it is possible to target mitochondria of macrophages and/or M cells with mitochondria-targeted NPs for therapeutic vaccine [181]. Fievez et al. [182] reported NPs with non-peptide ligands for targeting $\mathrm{M}$ cells for oral vaccination. The targeted OVA NPs showed enhanced cellular immune response with high levels of IFN- $\gamma$ production and consistently low levels of IL-4 in splenocytes. In vivo studies in mice indicated higher IgG immune response than non-targeted formulations. Chen et al. [183] reported liposomal NPs as antigen delivery systems for macrophages. By decorating liposomes with 3'-BPCNeuAc ligands and glycan ligand, delivery of the antigens to endosomes and lysosomes, respectively, were achieved. Results demonstrated that liposomal NPs were efficient in delivering OVA to bone marrow derived macrophages and significantly enhanced $\mathrm{T}$ cell proliferation. By modifying the liposome with mitochondria targeting moiety, it will be possible to target the antigen NPs into mitochondria for efficient antigen delivery and immune response. Zhou et al. [184] reported that graphene nanosheets of diameter $172.7 \pm 75.6 \mathrm{~nm}$ and of thickness 2-3 nm induced the secretion of Th1/Th2 cytokines (IL-1 $\alpha$, IL-6, IL-10, TNF- $\alpha$ ) and chemokines (GM-CSF MCP-1, MIP-1 $\alpha$, MIP-1 $\beta$, RANTES) in murine macrophages. These settings of NPs can be potentially designed to target mitochondria by conjugating or surface modified with mitochondria targeting moiety.

Most human tumors are MHC class II negative, which $\mathrm{CD}^{+} \mathrm{T}$ cells cannot recognize. NPs have potential to elicit the immunomodulatory cytokines which favor the proliferation and differentiation of 
cell-mediated immunity. Sena et al. [13] reported that increased mitochondrial ROS was able to produce nuclear factor of activated T cells and subsequent IL-2 cytokine expression. Specifically, the study demonstrated that mitochondrial complex III ROS is required for $\mathrm{CD}^{+} \mathrm{T}$ cell activation in mice model. The Uqcrfs1 $1^{-/-}$T cells, lacking mitochondrial complex III ROS and mitochondrial production of ATP, and controls WT CD4 ${ }^{+}$T cells were isolated from Cd4-cre mice, which had the same cell viability after $24 \mathrm{~h}$ of cell culture. The Uqcrfs1 ${ }^{-/-} \mathrm{CD} 4^{+} \mathrm{T}$ cells failed to induce IL-2 and were less activated (reduced CD69 and CD25 markers) in response to anti-CD3 and anti-CD28 stimulation. Hence, mitochondria targeting to immune cells (e.g., T cell, natural killer cells) by NP-systems can be a promising method to enhance cytokine generation efficiency via mitochondria pathways.

Some efforts were made towards using NPs to potentiate cytokine generation for immune response. For example, Hanley et al. [185] reported ZnO NPs as modulators of pro-inflammatory cytokines, IFN- $\gamma, \mathrm{TNF}-\alpha$, and IL-12 in primary human immune cells. ZnO NPs with size range of 4-20 nm were prepared by forced hydrolysis of zinc acetate. The 8-nm ZnO NPs were used to evaluate the generation of cytokines of immune cells in isolated peripheral blood mononuclear cells (PBMC). A pretreatment with low level of IFN- $\gamma$ before treatment by ZnO NPs resulted in a significant amount of IL-12 expression, indicative of a synergistic relationship between ZnO NPs and IFN- $\gamma$. The ZnO NP treated PBMC showed significant enhancement of IL-12, IFN- $\gamma$, and TNF- $\alpha$ cytokine levels, which were dose dependent for ZnO NP. The cytokines (IFN- $\gamma$, TNF- $\alpha$, and IL-12) produced by $\mathrm{ZnO}$ NPs aided in antigen processing and immune cell differentiation for enhanced destruction of cancerous cells, virally infected cells, and/or intracellular pathogens. ZnO NPs are also reported to enhance inflammatory cytokines levels in murine macrophages [186]. Liu et al. [187] reported that poly-hydroxylated metallofullerenol [Gd@ $\left.\mathrm{C}_{82}(\mathrm{OH})_{22}\right]_{\mathrm{n}}$ modulates levels of Th1 (IL-2, IFN- $\gamma$, and TNF- $\alpha$ ) and Th2 (IL-4, IL-5, and IL-6) cytokines in T cells and macrophages. The ratio of CD4 ${ }^{+}$to CD8 ${ }^{+} \mathrm{T}$ cells was significantly increased by $\left[\mathrm{Gd} @ \mathrm{C}_{82}(\mathrm{OH})_{22}\right]_{n}$ treatment. Polyvinylpyrrolidone (PVP)-PEG-Ag nanorods were reported for HIV vaccine [188]. Au NPs were modified with glycopolymer to be used as synthetic cancer vaccines [189] and showed strong antibody production. Further modification of these sets of NPs by mitochondria targeting moiety can potentially modulate immune response.

\section{Conclusions and Future Outlook}

Mitochondria play critical roles in cell life and death, and their dysfunction is indicative of mitochondria-associated diseases. An ever-increasing number of investigations are focused on mitochondria targeting for efficient disease therapeutics, indicating the potential for such strategy in preventive/therapeutic vaccine. Possible roles for targeting mitochondria in vaccine development can be: (1) as targets of APCs (e.g., DCs) for external antigen delivery systems; (2) as targeting sites of immune cells activation (e.g., T and B cell); (3) as targets in dysfunctional cells (e.g., tumor cells) for apoptosis and production of TAAs available for APC uptake and subsequent activation of immune cells. NP-based vaccine systems are promising for: (1) carriers for delivery of external antigens; (2) inducers of apoptosis for release of internal antigens; and/or (3) inducers of cytokine production via due to their intrinsic properties. There are relatively fewer studies concerning mitochondria-targeted NP vaccine delivery systems. Mitochondrial targeting NP systems can provide for both cell-mediated (Th1; CD8 ${ }^{+} \mathrm{T}$ cell) and humoral (Th2; B cell) immune response via activation of various pathways, such as complex III, ROS, and are promising tools for vaccines with effective immune responses. To achieve the mitochondria targeting purpose, the well-developed antigen nanocarriers, consisting of polymer-based and liposome-based antigen delivery systems, should be modified with a mitochondria targeting moiety, such as TPP or MTS, in order to direct antigen systems to the mitochondria. NP based vaccine delivery system has been shown to be a promising method for enhancing vaccine efficacies and can potentially be translated in to a worldwide immunization scope in the near future.

Acknowledgments: We thank the Department of Defense Prostate Cancer Idea award (W81XWH-12-1-0406); American Heart Association National Scientist Award (14SDG18690009); National Heart, Lung, and Blood Institute of National Institutes of Health (NIH) under award number R56HL121392; National Institute of Neurological 
Disorders and Stroke of NIH under award number R01NS093314 and Georgia Research Alliance for supporting various projects related to nanoparticle-based technologies in our lab.

Author Contributions: R.W., A.C.U., L.F., S.T. and S.D. wrote the paper. N.S. participated in the construction of Table 2.

Conflicts of Interest: S.D. discloses financial interest in Partikula LLC. All other authors declare no conflict of interest.

\section{References}

1. Liu, M.A. Immunologic basis of vaccine vectors. Immunity 2010, 33, 504-515. [CrossRef] [PubMed]

2. Geels, M.; Ye, K. Developments in high-yield system expressed vaccines and immunotherapy. Recent Pat. Biotechnol. 2010, 4, 189-197. [CrossRef] [PubMed]

3. Irvine, D.J.; Hanson, M.C.; Rakhra, K.; Tokatlian, T. Synthetic nanoparticles for vaccines and immunotherapy. Chem. Rev. 2015, 115, 11109-11146. [CrossRef] [PubMed]

4. Rice-Ficht, A.C.; Arenas-Gamboa, A.M.; Kahl-McDonagh, M.M.; Ficht, T.A. Polymeric particles in vaccine delivery. Curr. Opin. Microbiol. 2010, 13, 106-112. [CrossRef] [PubMed]

5. Bachmann, M.F.; Jennings, G.T. Vaccine delivery: A matter of size, geometry, kinetics and molecular patterns. Nat. Rev. Immunol. 2010, 10, 787-796. [CrossRef] [PubMed]

6. Zhao, L.; Seth, A.; Wibowo, N.; Zhao, C.X.; Mitter, N.; Yu, C.; Middelberg, A.P. Nanoparticle vaccines. Vaccine 2014, 32, 327-337. [CrossRef] [PubMed]

7. Wen, R.; Banik, B.; Pathak, R.K.; Kumar, A.; Kolishetti, N.; Dhar, S. Nanotechnology inspired tools for mitochondrial dysfunction related diseases. Adv. Drug Deliv. Rev. 2016, 99, 52-69. [CrossRef] [PubMed]

8. Chan, D.C. Mitochondria: Dynamic organelles in disease, aging, and development. Cell 2006, 125, 1241-1252. [CrossRef] [PubMed]

9. Pathak, R.K.; Kolishetti, N.; Dhar, S. Targeted nanoparticles in mitochondrial medicine. Wiley Interdiscip. Rev. Nanomed. Nanobiotechnol. 2015, 7, 315-329. [CrossRef] [PubMed]

10. Duchen, M.R. Mitochondria in health and disease: Perspectives on a new mitochondrial biology. Mol. Aspects Med. 2004, 25, 365-451. [CrossRef] [PubMed]

11. Marrache, S.; Kumar Pathak, R.; Darley, K.L.; Choi, J.H.; Zaver, D.; Kolishetti, N.; Dhar, S. Nanocarriers for tracking and treating diseases. Curr. Med. Chem. 2013, 20, 3500-3514. [CrossRef] [PubMed]

12. West, A.P.; Shadel, G.S.; Ghosh, S. Mitochondria in innate immune responses. Nat. Rev. Immunol. 2011, 11, 389-402. [CrossRef] [PubMed]

13. Sena, L.A.; Li, S.; Jairaman, A.; Prakriya, M.; Ezponda, T.; Hildeman, D.A.; Wang, C.R.; Schumacker, P.T.; Licht, J.D.; Perlman, H.; et al. Mitochondria are required for antigen-specific T cell activation through reactive oxygen species signaling. Immunity 2013, 38, 225-236. [CrossRef] [PubMed]

14. Yan, W.; Chen, W.; Huang, L. Reactive oxygen species play a central role in the activity of cationic liposome based cancer vaccine. J. Control. Release 2008, 130, 22-28. [CrossRef] [PubMed]

15. Yeaman, S.; Danner, D.; Mutimer, D.; Fussey, S.; James, O.; Bassendine, M. Primary biliary cirrhosis: Identification of two major M2 mitochondrial autoantigens. Lancet 1988, 331, 1067-1070. [CrossRef]

16. Fussey, S.P.; Lindsay, J.G.; Fuller, C.; Perham, R.N.; Dale, S.; James, O.F.; Bassendine, M.F.; Yeaman, S.J. Autoantibodies in primary biliary cirrhosis: Analysis of reactivity against eukaryotic and prokaryotic 2-oxo acid dehydrogenase complexes. Hepatology 1991, 13, 467-474. [CrossRef] [PubMed]

17. Moteki, S.; Leung, P.; Dickson, E.R.; Van Thiel, D.H.; Galperin, C.; Buch, T.; Alarcon-Segovia, D.; Kershenobich, D.; Kawano, K.; Coppel, R.L. Epitope mapping and reactivity of autoantibodies to the E2 component of 2-oxoglutarate dehydrogenase complex in primary biliary cirrhosis using recombinant 2*oxoglutarate dehydrogenase complex. Hepatology 1996, 23, 436-444. [CrossRef] [PubMed]

18. Chen, L.; Duvvuri, B.; Grigull, J.; Jamnik, R.; Wither, J.E.; Wu, G.E. Experimental evidence that mutated-self peptides derived from mitochondrial DNA somatic mutations have the potential to trigger autoimmunity. Hum. Immunol. 2014, 75, 873-879. [CrossRef] [PubMed]

19. Gershwin, M.E.; Mackay, I.; Sturgess, A.; Coppel, R. Identification and specificity of a cDNA encoding the $70 \mathrm{kd}$ mitochondrial antigen recognized in primary biliary cirrhosis. J. Immunol. 1987, 138, 3525-3531. [PubMed] 
20. Marrache, S.; Tundup, S.; Harn, D.A.; Dhar, S. Ex vivo programming of dendritic cells by mitochondria-targeted nanoparticles to produce interferon-gamma for cancer immunotherapy. ACS Nano 2013, 7, 7392-7402. [CrossRef] [PubMed]

21. Pierini, S.; Fang, C.; Rafail, S.; Facciponte, J.G.; Huang, J.; De Sanctis, F.; Morgan, M.A.; Uribe-Herranz, M.; Tanyi, J.L.; Facciabene, A. A tumor mitochondria vaccine protects against experimental renal cell carcinoma. J. Immunol. 2015, 195, 4020-4027. [CrossRef] [PubMed]

22. West, A.P.; Khoury-Hanold, W.; Staron, M.; Tal, M.C.; Pineda, C.M.; Lang, S.M.; Bestwick, M.; Duguay, B.A.; Raimundo, N.; MacDuff, D.A.; et al. Mitochondrial DNA stress primes the antiviral innate immune response. Nature 2015, 520, 553-557. [CrossRef] [PubMed]

23. Smith, R.; Huston, M.M.; Jenkins, R.N.; Huston, D.P.; Rich, R.R. Mitochondria control expression of a murine cell surface antigen. Nature 1983, 306, 599-601. [CrossRef] [PubMed]

24. Loveland, B.; Wang, C.R.; Yonekawa, H.; Hermel, E.; Lindahl, K.F. Maternally transmitted histocompatibility antigen of mice: A hydrophobic peptide of a mitochondrially encoded protein. Cell 1990, 60, 971-980. [CrossRef]

25. Kita, H.; Matsumura, S.; He, X.S.; Ansari, A.A.; Lian, Z.X.; Van de Water, J.; Coppel, R.L.; Kaplan, M.M.; Gershwin, M.E. Quantitative and functional analysis of PDC-E2-specific autoreactive cytotoxic T lymphocytes in primary biliary cirrhosis. J. Clin. Invest. 2002, 109, 1231-1240. [CrossRef] [PubMed]

26. Berard, M.; Mondière, P.; Casamayor-Pallejà, M.; Hennino, A.; Bella, C.; Defrance, T. Mitochondria connects the antigen receptor to effector caspases during B cell receptor-induced apoptosis in normal human B cells. J. Immunol. 1999, 163, 4655-4662. [PubMed]

27. Marrache, S.; Tundup, S.; Harn, D.A.; Dhar, S. Ex Vivo Generation of functional immune cells by mitochondria-targeted photosensitization of cancer cells. Methods Mol. Biol. 2015, 2, 113-122.

28. Marrache, S.; Choi, J.H.; Tundup, S.; Zaver, D.; Harn, D.A.; Dhar, S. Immune stimulating photoactive hybrid nanoparticles for metastatic breast cancer. Integr. Biol. 2013, 5, 215-223. [CrossRef] [PubMed]

29. Panneerselvam, P.; Singh, L.; Selvarajan, V.; Chng, W.J.; Ng, S.; Tan, N.; Ho, B.; Chen, J.; Ding, J.L. T-cell death following immune activation is mediated by mitochondria-localized SARM. Cell Death Differ. 2013, 20, 478-489. [CrossRef] [PubMed]

30. Van de Water, J.; Ansari, A.; Surh, C.; Coppel, R.; Roche, T.; Bonkovsky, H.; Kaplan, M.; Gershwin, M. Evidence for the targeting by 2-oxo-dehydrogenase enzymes in the $\mathrm{T}$ cell response of primary biliary cirrhosis. J. Immunol. 1991, 146, 89-94. [PubMed]

31. Murphy, M.P.; Siegel, R.M. Mitochondrial ROS fire up T cell activation. Immunity 2013, 38, $201-202$. [CrossRef] [PubMed]

32. Storni, T.; Kündig, T.M.; Senti, G.; Johansen, P. Immunity in response to particulate antigen-delivery systems. Adv. Drug Deliv. Rev. 2005, 57, 333-355. [CrossRef] [PubMed]

33. Jewell, C.M.; López, S.C.; Irvine, D.J. In situ engineering of the lymph node microenvironment via intranodal injection of adjuvant-releasing polymer particles. Proc. Natl. Acad. Sci. USA 2011, 108, 15745-15750. [CrossRef] [PubMed]

34. Demento, S.L.; Cui, W.; Criscione, J.M.; Stern, E.; Tulipan, J.; Kaech, S.M.; Fahmy, T.M. Role of sustained antigen release from nanoparticle vaccines in shaping the T cell memory phenotype. Biomaterials 2012, 33, 4957-4964. [CrossRef] [PubMed]

35. Rahimian, S.; Kleinovink, J.W.; Fransen, M.F.; Mezzanotte, L.; Gold, H.; Wisse, P.; Overkleeft, H.; Amidi, M.; Jiskoot, W.; Löwik, C.W. Near-infrared labeled, ovalbumin loaded polymeric nanoparticles based on a hydrophilic polyester as model vaccine: In vivo tracking and evaluation of antigen-specific CD8 ${ }^{+} \mathrm{T}$ cell immune response. Biomaterials 2015, 37, 469-477. [CrossRef] [PubMed]

36. Rahimian, S.; Fransen, M.F.; Kleinovink, J.W.; Christensen, J.R.; Amidi, M.; Hennink, W.E.; Ossendorp, F. Polymeric nanoparticles for co-delivery of synthetic long peptide antigen and poly IC as therapeutic cancer vaccine formulation. J. Control. Release 2015, 203, 16-22. [CrossRef] [PubMed]

37. Cruz, L.J.; Tacken, P.J.; Fokkink, R.; Joosten, B.; Stuart, M.C.; Albericio, F.; Torensma, R.; Figdor, C.G. Targeted PLGA nano-but not microparticles specifically deliver antigen to human dendritic cells via DC-SIGN in vitro. J. Control. Release 2010, 144, 118-126. [CrossRef] [PubMed]

38. Chong, C.S.; Cao, M.; Wong, W.W.; Fischer, K.P.; Addison, W.R.; Kwon, G.S.; Tyrrell, D.L.; Samuel, J. Enhancement of $\mathrm{T}$ helper type 1 immune responses against hepatitis $\mathrm{B}$ virus core antigen by PLGA nanoparticle vaccine delivery. J. Control. Release 2005, 102, 85-99. [CrossRef] [PubMed] 
39. Wendorf, J.; Chesko, J.; Kazzaz, J.; Ugozzoli, M.; Vajdy, M.; O’Hagan, D.; Singh, M. A comparison of anionic nanoparticles and microparticles as vaccine delivery systems. Hum. Vaccin. 2008, 4, 44-49. [CrossRef] [PubMed]

40. Solbrig, C.; Saucier-Sawyer, J.; Cody, V.; Saltzman, W.; Hanlon, D. Polymer nanoparticles for immunotherapy from encapsulated tumor-associated antigens and whole tumor cells. Mol. Pharm. 2007, 4, 47-57. [CrossRef] [PubMed]

41. Diwan, M.; Elamanchili, P.; Cao, M.; Samuel, J. Dose sparing of CpG oligodeoxynucleotide vaccine adjuvants by nanoparticle delivery. Curr. Drug Deliv. 2004, 1, 405-412. [CrossRef] [PubMed]

42. Danhier, F.; Ansorena, E.; Silva, J.M.; Coco, R.; Le Breton, A.; Préat, V. PLGA-based nanoparticles: An overview of biomedical applications. J. Control. Release 2012, 161, 505-522. [CrossRef] [PubMed]

43. Hamdy, S.; Molavi, O.; Ma, Z.; Haddadi, A.; Alshamsan, A.; Gobti, Z.; Elhasi, S.; Samuel, J.; Lavasanifar, A. Co-delivery of cancer-associated antigen and Toll-like receptor 4 ligand in PLGA nanoparticles induces potent $\mathrm{CD}^{+} \mathrm{T}$ cell-mediated anti-tumor immunity. Vaccine 2008, 26, 5046-5057. [CrossRef] [PubMed]

44. Cruz, L.J.; Tacken, P.J.; Fokkink, R.; Figdor, C.G. The influence of PEG chain length and targeting moiety on antibody-mediated delivery of nanoparticle vaccines to human dendritic cells. Biomaterials 2011, 32, 6791-6803. [CrossRef] [PubMed]

45. Bivas-Benita, M.; Lin, M.Y.; Bal, S.M.; van Meijgaarden, K.E.; Franken, K.L.; Friggen, A.H.; Junginger, H.E.; Borchard, G.; Klein, M.R.; Ottenhoff, T.H. Pulmonary delivery of DNA encoding Mycobacterium tuberculosis latency antigen Rv1733c associated to PLGA-PEI nanoparticles enhances $\mathrm{T}$ cell responses in a DNA prime/protein boost vaccination regimen in mice. Vaccine 2009, 27, 4010-4017. [CrossRef] [PubMed]

46. Prego, C.; Paolicelli, P.; Díaz, B.; Vicente, S.; Sánchez, A.; González-Fernández, Á.; Alonso, M.J. Chitosan-based nanoparticles for improving immunization against hepatitis B infection. Vaccine 2010, 28, 2607-2614. [CrossRef] [PubMed]

47. Barzegar-Jalali, M. Nanovaccine for leishmaniasis: Preparation of chitosan nanoparticles containing Leishmania superoxide dismutase and evaluation of its immunogenicity in BALB/c mice. Int. J. Nanomedicine 2011, 6, 835-842.

48. Vila, A.; Sánchez, A.; Janes, K.; Behrens, I.; Kissel, T.; Jato, J.L.; Alonso, M.J. Low molecular weight chitosan nanoparticles as new carriers for nasal vaccine delivery in mice. Eur. J. Pharm. Biopharm. 2004, 57, 123-131. [CrossRef] [PubMed]

49. Correia-Pinto, J.F.; Csaba, N.; Schiller, J.T.; Alonso, M.J. Chitosan-poly (I: C)-PADRE based nanoparticles as delivery vehicles for synthetic peptide vaccines. Vaccines 2015, 3, 730-750. [CrossRef] [PubMed]

50. Sarti, F.; Perera, G.; Hintzen, F.; Kotti, K.; Karageorgiou, V.; Kammona, O.; Kiparissides, C.; Bernkop-Schnürch, A. In vivo evidence of oral vaccination with PLGA nanoparticles containing the immunostimulant monophosphoryl lipid A. Biomaterials 2011, 32, 4052-4057. [CrossRef] [PubMed]

51. Ataman-Önal, Y.; Munier, S.; Ganée, A.; Terrat, C.; Durand, P.Y.; Battail, N.; Martinon, F.; Le Grand, R.; Charles, M.H.; Delair, T. Surfactant-free anionic PLA nanoparticles coated with HIV-1 p24 protein induced enhanced cellular and humoral immune responses in various animal models. J. Control. Release 2006, 112, 175-185. [CrossRef] [PubMed]

52. Okamoto, S.; Yoshii, H.; Akagi, T.; Akashi, M.; Ishikawa, T.; Okuno, Y.; Takahashi, M.; Yamanishi, K.; Mori, Y. Influenza hemagglutinin vaccine with poly ( $\gamma$-glutamic acid) nanoparticles enhances the protection against influenza virus infection through both humoral and cell-mediated immunity. Vaccine 2007, 25, 8270-8278. [CrossRef] [PubMed]

53. Singh, J.; Pandit, S.; Bramwell, V.W.; Alpar, H.O. Diphtheria toxoid loaded poly-( $\varepsilon$-caprolactone) nanoparticles as mucosal vaccine delivery systems. Methods 2006, 38, 96-105. [CrossRef] [PubMed]

54. Hirosue, S.; Kourtis, I.C.; van der Vlies, A.J.; Hubbell, J.A.; Swartz, M.A. Antigen delivery to dendritic cells by poly (propylene sulfide) nanoparticles with disulfide conjugated peptides: Cross-presentation and $\mathrm{T}$ cell activation. Vaccine 2010, 28, 7897-7906. [CrossRef] [PubMed]

55. Thomas, C.; Rawat, A.; Hope-Weeks, L.; Ahsan, F. Aerosolized PLA and PLGA nanoparticles enhance humoral, mucosal and cytokine responses to hepatitis B vaccine. Mol. Pharm. 2011, 8, 405-415. [CrossRef] [PubMed]

56. Marrache, S.; Dhar, S. Engineering of blended nanoparticle platform for delivery of mitochondria-acting therapeutics. Proc. Natl. Acad. Sci. USA 2012, 109, 16288-16293. [CrossRef] [PubMed] 
57. Jain, A.K.; Goyal, A.K.; Mishra, N.; Vaidya, B.; Mangal, S.; Vyas, S.P. PEG-PLA-PEG block copolymeric nanoparticles for oral immunization against hepatitis B. Int. J. Pharm. 2010, 387, 253-262. [CrossRef] [PubMed]

58. Gou, M.; Dai, M.; Li, X.; Yang, L.; Huang, M.; Wang, Y.; Kan, B.; Lu, Y.; Wei, Y.; Qian, Z. Preparation of mannan modified anionic PCL-PEG-PCL nanoparticles at one-step for bFGF antigen delivery to improve humoral immunity. Colloids Surf. B: Biointerfaces 2008, 64, 135-139. [CrossRef] [PubMed]

59. Slütter, B.; Bal, S.; Keijzer, C.; Mallants, R.; Hagenaars, N.; Que, I.; Kaijzel, E.; van Eden, W.; Augustijns, P.; Löwik, C. Nasal vaccination with N-trimethyl chitosan and PLGA based nanoparticles: Nanoparticle characteristics determine quality and strength of the antibody response in mice against the encapsulated antigen. Vaccine 2010, 28, 6282-6291. [CrossRef] [PubMed]

60. Ito, A.; Shinkai, M.; Honda, H.; Kobayashi, T. Medical application of functionalized magnetic nanoparticles. J. Biosci. Bioeng. 2005, 100, 1-11. [CrossRef] [PubMed]

61. Ellens, H.; Bentz, J.; Szoka, F.C. Fusion of phosphatidylethanolamine-containing liposomes and mechanism of L. alpha.-HII phase transition. Biochemistry 1986, 25, 4141-4147. [CrossRef] [PubMed]

62. Cui, Z.; Mumper, R.J. The effect of co-administration of adjuvants with a nanoparticle-based genetic vaccine delivery system on the resulting immune responses. Eur. J. Pharm. Biopharm. 2003, 55, 11-18. [CrossRef]

63. Krishnamachari, Y.; Geary, S.M.; Lemke, C.D.; Salem, A.K. Nanoparticle delivery systems in cancer vaccines. Pharm. Res. 2011, 28, 215-236. [CrossRef] [PubMed]

64. Diebold, Y.; Jarrín, M.; Sáez, V.; Carvalho, E.L.; Orea, M.; Calonge, M.; Seijo, B.; Alonso, M.J. Ocular drug delivery by liposome-chitosan nanoparticle complexes (LCS-NP). Biomaterials 2007, 28, 1553-1564. [CrossRef] [PubMed]

65. Jeong, J.M.; Chung, Y.C.; Hwang, J.H. Enhanced adjuvantic property of polymerized liposome as compared to a phospholipid liposome. J. Biotechnol. 2002, 94, 255-263. [CrossRef]

66. Chen, H.; Torchilin, V.; Langer, R. Polymerized liposomes as potential oral vaccine carriers: Stability and bioavailability. J. Control. Release 1996, 42, 263-272. [CrossRef]

67. Malam, Y.; Loizidou, M.; Seifalian, A.M. Liposomes and nanoparticles: Nanosized vehicles for drug delivery in cancer. Trends Pharmacol. Sci. 2009, 30, 592-599. [CrossRef] [PubMed]

68. Bhargava, A.; Mishra, D.; Khan, S.; Varshney, S.K.; Banerjee, S.; Mishra, P.K. Assessment of tumor antigen-loaded solid lipid nanoparticles as an efficient delivery system for dendritic cell engineering. Nanomedicine 2013, 8, 1067-1084. [CrossRef] [PubMed]

69. Meidenbauer, N.; Harris, D.; Spitler, L.; Whiteside, T. Generation of PSA-reactive effector cells after vaccination with a PSA-based vaccine in patients with prostate cancer. Prostate 2000, 43, 88-100. [CrossRef]

70. North, S.A.; Graham, K.; Bodnar, D.; Venner, P. A pilot study of the liposomal MUC1 vaccine BLP25 in prostate specific antigen failures after radical prostatectomy. J. Urol. 2006, 176, 91-95. [CrossRef]

71. Butts, C.; Socinski, M.A.; Mitchell, P.L.; Thatcher, N.; Havel, L.; Krzakowski, M.; Nawrocki, S.; Ciuleanu, T.E.; Bosquée, L.; Trigo, J.M.; et al. Tecemotide (L-BLP25) versus placebo after chemoradiotherapy for stage III non-small-cell lung cancer (START): A randomised, double-blind, phase 3 trial. Lancet Oncol. 2014, 15, 59-68. [CrossRef]

72. Villa, C.H.; Dao, T.; Ahearn, I.; Fehrenbacher, N.; Casey, E.; Rey, D.A.; Korontsvit, T.; Zakhaleva, V.; Batt, C.A.; Philips, M.R. Single-walled carbon nanotubes deliver peptide antigen into dendritic cells and enhance IgG responses to tumor-associated antigens. ACS Nano 2011, 5, 5300-5311. [CrossRef] [PubMed]

73. Kuang, Y.; Zhao, L.; Zhang, S.; Zhang, F.; Dong, M.; Xu, S. Morphologies, preparations and applications of layered double hydroxide micro-/nanostructures. Materials 2010, 3, 5220-5235. [CrossRef]

74. Xu, Z.P.; Niebert, M.; Porazik, K.; Walker, T.L.; Cooper, H.M.; Middelberg, A.P.; Gray, P.P.; Bartlett, P.F.; Lu, G.Q. Subcellular compartment targeting of layered double hydroxide nanoparticles. J. Control. Release 2008, 130, 86-94. [CrossRef] [PubMed]

75. Yan, S.; Rolfe, B.E.; Zhang, B.; Mohammed, Y.H.; Gu, W.; Xu, Z.P. Polarized immune responses modulated by layered double hydroxides nanoparticle conjugated with CpG. Biomaterials 2014, 35, 9508-9516. [CrossRef] [PubMed]

76. Wang, J.; Zhu, R.; Gao, B.; Wu, B.; Li, K.; Sun, X.; Liu, H.; Wang, S. The enhanced immune response of hepatitis B virus DNA vaccine using $\mathrm{SiO}_{2} @ \mathrm{LDH}$ nanoparticles as an adjuvant. Biomaterials 2014, 35, 466-478. [CrossRef] [PubMed] 
77. Wang, D.; Christopher, M.E.; Nagata, L.P.; Zabielski, M.A.; Li, H.; Wong, J.P.; Samuel, J. Intranasal immunization with liposome-encapsulated plasmid DNA encoding influenza virus hemagglutinin elicits mucosal, cellular and humoral immune responses. J. Clin. Virol. 2004, 31, 99-106. [CrossRef] [PubMed]

78. Ito, A.; Matsuoka, F.; Honda, H.; Kobayashi, T. Antitumor effects of combined therapy of recombinant heat shock protein 70 and hyperthermia using magnetic nanoparticles in an experimental subcutaneous murine melanoma. Cancer Immunol. Immunother. 2004, 53, 26-32. [CrossRef] [PubMed]

79. Alvarez, M.; Echechipia, S.; Garcia, B.; Tabar, A.; Martin, S.; Rico, P.; Olaguibel, J. Liposome-entrapped D. pteronyssinus vaccination in mild asthma patients: Effect of 1-year double-blind, placebo-controlled trial on inflammation, bronchial hyper-responsiveness and immediate and late bronchial responses to the allergen. Clin. Exp. Allergy 2002, 32, 1574-1582. [CrossRef] [PubMed]

80. Rosada, R.S.; de la Torre, L.G.; Frantz, F.G.; Trombone, A.P.; Zárate-Bladés, C.R.; Fonseca, D.M.; Souza, P.R.; Brandão, I.T.; Masson, A.P.; Soares, É.G.; et al. Protection against tuberculosis by a single intranasal administration of DNA-hsp65 vaccine complexed with cationic liposomes. BMC Immunol. 2008, 9, 1-13. [CrossRef] [PubMed]

81. Just, M.; Berger, R.; Drechsler, H.; Brantschen, S.; Glück, R. A single vaccination with an inactivated hepatitis A liposome vaccine induces protective antibodies after only two weeks. Vaccine 1992, 10, 737-739. [CrossRef]

82. Zheng, L.; Huang, X.L.; Fan, Z.; Borowski, L.; Wilson, C.C.; Rinaldo, C.R. Delivery of liposome-encapsulated HIV type 1 proteins to human dendritic cells for stimulation of HIV type 1-specific memory cytotoxic T lymphocyte responses. AIDS Res. Hum. Retroviruses 1999, 15, 1011-1020. [CrossRef] [PubMed]

83. Wilson, K.D.; de Jong, S.D.; Tam, Y.K. Lipid-based delivery of CpG oligonucleotides enhances immunotherapeutic efficacy. Adv. Drug Deliv. Rev. 2009, 61, 233-242. [CrossRef] [PubMed]

84. Almeida, A.J.; Souto, E. Solid lipid nanoparticles as a drug delivery system for peptides and proteins. Adv. Drug Deliv. Rev. 2007, 59, 478-490. [CrossRef] [PubMed]

85. Cui, Z.; Huang, L. Liposome-polycation-DNA (LPD) particle as a carrier and adjuvant for protein-based vaccines: Therapeutic effect against cervical cancer. Cancer Immunol. Immunother. 2005, 54, 1180-1190. [CrossRef] [PubMed]

86. Kumar, A.; Kolar, S.S.; Zao, M.; McDermott, A.M.; Cai, C. Localization of antimicrobial peptides on polymerized liposomes leading to their enhanced efficacy against Pseudomonas aeruginosa. Mol. BioSyst. 2011, 7, 711-713. [CrossRef] [PubMed]

87. Kossovsky, N.; Gelman, A.; Hnatyszyn, H.J.; Rajguru, S.; Garrell, R.L.; Torbati, S.; Freitas, S.S.; Chow, G.M. Surface-modified diamond nanoparticles as antigen delivery vehicles. Bioconjugate Chem. 1995, 6, 507-511. [CrossRef]

88. Mendonça, E.; Diniz, M.; Silva, L.; Peres, I.; Castro, L.; Correia, J.B.; Picado, A. Effects of diamond nanoparticle exposure on the internal structure and reproduction of Daphnia magna. J. Hazard Mater. 2011, 186, 265-271. [CrossRef] [PubMed]

89. Safari, D.; Marradi, M.; Chiodo, F.; Th Dekker, H.A.; Shan, Y.; Adamo, R.; Oscarson, S.; Rijkers, G.T.; Lahmann, M.; Kamerling, J.P. Gold nanoparticles as carriers for a synthetic Streptococcus pneumoniae type 14 conjugate vaccine. Nanomedicine 2012, 7, 651-662. [CrossRef] [PubMed]

90. Lee, I.H.; Kwon, H.K.; An, S.; Kim, D.; Kim, S.; Yu, M.K.; Lee, J.H.; Lee, T.S.; Im, S.H.; Jon, S. Imageable Antigen-Presenting Gold Nanoparticle Vaccines for Effective Cancer Immunotherapy In Vivo. Angew. Chem. 2012, 124, 8930-8935. [CrossRef]

91. Rogers, J.V.; Parkinson, C.V.; Choi, Y.W.; Speshock, J.L.; Hussain, S.M. A preliminary assessment of silver nanoparticle inhibition of monkeypox virus plaque formation. Nanoscale Res. Lett. 2008, 3, 129-133. [CrossRef]

92. Lara, H.H.; Ayala-Nuñez, N.V.; Ixtepan-Turrent, L.; Rodriguez-Padilla, C. Mode of antiviral action of silver nanoparticles against HIV-1. J. Nanobiotechnol. 2010, 8, 1-8. [CrossRef] [PubMed]

93. Frey, A.; Neutra, M.R.; Robey, F.A. Peptomer aluminum oxide nanoparticle conjugates as systemic and mucosal vaccine candidates: Synthesis and characterization of a conjugate derived from the C4 domain of HIV-1MN gp120. Bioconjugate Chem. 1997, 8, 424-433. [CrossRef] [PubMed]

94. Uto, T.; Akagi, T.; Toyama, M.; Nishi, Y.; Shima, F.; Akashi, M.; Baba, M. Comparative activity of biodegradable nanoparticles with aluminum adjuvants: Antigen uptake by dendritic cells and induction of immune response in mice. Immunol. Lett. 2011, 140, 36-43. [CrossRef] [PubMed] 
95. Moon, J.J.; Suh, H.; Bershteyn, A.; Stephan, M.T.; Liu, H.; Huang, B.; Sohail, M.; Luo, S.; Um, S.H.; Khant, H. Interbilayer-crosslinked multilamellar vesicles as synthetic vaccines for potent humoral and cellular immune responses. Nat. Mater. 2011, 10, 243-251. [CrossRef] [PubMed]

96. Plummer, E.M.; Manchester, M. Viral nanoparticles and virus-like particles: Platforms for contemporary vaccine design. Wiley Interdiscip. Rev. Nanomed. Nanobiotechnol. 2011, 3, 174-196. [CrossRef] [PubMed]

97. Savard, C.; Laliberté-Gagné, M.Ė.; Babin, C.; Bolduc, M.; Guérin, A.; Drouin, K.; Forget, M.A.; Majeau, N.; Lapointe, R.; Leclerc, D. Improvement of the PapMV nanoparticle adjuvant property through an increased of its avidity for the antigen [influenza NP]. Vaccine 2012, 30, 2535-2542. [CrossRef] [PubMed]

98. Okuno, J.; Maehashi, K.; Kerman, K.; Takamura, Y.; Matsumoto, K.; Tamiya, E. Label-free immunosensor for prostate-specific antigen based on single-walled carbon nanotube array-modified microelectrodes. Biosens. Bioelectron. 2007, 22, 2377-2381. [CrossRef] [PubMed]

99. Wang, T.; Jiang, H.; Zhao, Q.; Wang, S.; Zou, M.; Cheng, G. Enhanced mucosal and systemic immune responses obtained by porous silica nanoparticles used as an oral vaccine adjuvant: Effect of silica architecture on immunological properties. Int. J. Pharm. 2012, 436, 351-358. [CrossRef] [PubMed]

100. Goto, N.; Kato, H.; Maeyama, J.I.; Eto, K.; Yoshihara, S. Studies on the toxicities of aluminium hydroxide and calcium phosphate as immunological adjuvants for vaccines. Vaccine 1993, 11, 914-918. [CrossRef]

101. Aggerbeck, H.; Fenger, C.; Heron, I. Booster vaccination against diphtheria and tetanus in man. Comparison of calcium phosphate and aluminium hydroxide as adjuvants-II. Vaccine 1995, 13, 1366-1374. [CrossRef]

102. He, Q.; Mitchell, A.; Morcol, T.; Bell, S.J. Calcium phosphate nanoparticles induce mucosal immunity and protection against herpes simplex virus type 2. Clin. Diagn. Lab. Immunol. 2002, 9, 1021-1024. [CrossRef] [PubMed]

103. Jones, L.S.; Peek, L.J.; Power, J.; Markham, A.; Yazzie, B.; Middaugh, C.R. Effects of adsorption to aluminum salt adjuvants on the structure and stability of model protein antigens. J. Biol. Chem. 2005, 280, 13406-13414. [CrossRef] [PubMed]

104. Wang, S.; Liu, X.; Fisher, K.; Smith, J.G.; Chen, F.; Tobery, T.W.; Ulmer, J.B.; Evans, R.K.; Caulfield, M.J. Enhanced type I immune response to a hepatitis B DNA vaccine by formulation with calcium- or aluminum phosphate. Vaccine 2000, 18, 1227-1235. [CrossRef]

105. Ludwig, C.; Wagner, R. Virus-like particles-universal molecular toolboxes. Curr. Opin. Biotechnol. 2007, 18, 537-545. [CrossRef] [PubMed]

106. Crawford, S.E.; Labbe, M.; Cohen, J.; Burroughs, M.H.; Zhou, Y.J.; Estes, M.K. Characterization of virus-like particles produced by the expression of rotavirus capsid proteins in insect cells. J. Virol. 1994, 68, 5945-5952. [PubMed]

107. Storni, T.; Ruedl, C.; Schwarz, K.; Schwendener, R.A.; Renner, W.A.; Bachmann, M.F. Nonmethylated CG motifs packaged into virus-like particles induce protective cytotoxic $\mathrm{T}$ cell responses in the absence of systemic side effects. J. Immunol. 2004, 172, 1777-1785. [CrossRef] [PubMed]

108. Gahéry-Ségard, H.; Pialoux, G.; Charmeteau, B.; Sermet, S.; Poncelet, H.; Raux, M.; Tartar, A.; Lévy, J.P.; Gras-Masse, H.; Guillet, J.G. Multiepitopic B-and T-cell responses induced in humans by a human immunodeficiency virus type 1 lipopeptide vaccine. J. Virol. 2000, 74, 1694-1703. [CrossRef] [PubMed]

109. Klinguer, C.; David, D.; Kouach, M.; Wieruszeski, J.M.; Tartar, A.; Marzin, D.; Levy, J.P.; Gras-Masse, H. Characterization of a multi-lipopeptides mixture used as an HIV-1 vaccine candidate. Vaccine 1999, 18, 259-267. [CrossRef]

110. BenMohamed, L.; Wechsler, S.L.; Nesburn, A.B. Lipopeptide vaccines-yesterday, today, and tomorrow. Lancet Infect. Dis. 2002, 2, 425-431. [CrossRef]

111. Minigo, G.; Scholzen, A.; Tang, C.K.; Hanley, J.C.; Kalkanidis, M.; Pietersz, G.A.; Apostolopoulos, V.; Plebanski, M. Poly-l-lysine-coated nanoparticles: A potent delivery system to enhance DNA vaccine efficacy. Vaccine 2007, 25, 1316-1327. [CrossRef] [PubMed]

112. Locher, C.P.; Putnam, D.; Langer, R.; Witt, S.A.; Ashlock, B.M.; Levy, J.A. Enhancement of a human immunodeficiency virus env DNA vaccine using a novel polycationic nanoparticle formulation. Immunol. Lett. 2003, 90, 67-70. [CrossRef] [PubMed]

113. Jiang, L.; Qian, F.; He, X.; Wang, F.; Ren, D.; He, Y.; Li, K.; Sun, S.; Yin, C. Novel chitosan derivative nanoparticles enhance the immunogenicity of a DNA vaccine encoding hepatitis B virus core antigen in mice. J. Gene Med. 2007, 9, 253-264. [CrossRef] [PubMed] 
114. Gómez, S.; Gamazo, C.; San Roman, B.; Ferrer, M.; Sanz, M.L.; Espuelas, S.; Irache, J.M. Allergen immunotherapy with nanoparticles containing lipopolysaccharide from Brucella ovis. Eur. J. Pharm. Biopharm. 2008, 70, 711-717. [CrossRef] [PubMed]

115. Persing, D.H.; Coler, R.N.; Lacy, M.J.; Johnson, D.A.; Baldridge, J.R.; Hershberg, R.M.; Reed, S.G. Taking toll: Lipid A mimetics as adjuvants and immunomodulators. Trends Microbiol. 2002, 10, 32-37. [CrossRef]

116. Li, A.; Qin, L.; Wang, W.; Zhu, R.; Yu, Y.; Liu, H.; Wang, S. The use of layered double hydroxides as DNA vaccine delivery vector for enhancement of anti-melanoma immune response. Biomaterials 2011, 32, 469-477. [CrossRef] [PubMed]

117. Pathak, R.K.; Marrache, S.; Harn, D.A.; Dhar, S. Mito-DCA: A mitochondria targeted molecular scaffold for efficacious delivery of metabolic modulator dichloroacetate. ACS Chem. Biol. 2014, 9, 1178-1187. [CrossRef] [PubMed]

118. Biswas, S.; Dodwadkar, N.S.; Sawant, R.R.; Koshkaryev, A.; Torchilin, V.P. Surface modification of liposomes with rhodamine-123-conjugated polymer results in enhanced mitochondrial targeting. J. Drug Target. 2011, 19, 552-561. [CrossRef] [PubMed]

119. Midgley, M.; Thompson, C. The role of mitochondria in the uptake of methyltriphenylphosphonium ion by Saccharomyces cerevisiae. FEMS Microbiol. Lett. 1985, 26, 311-315. [CrossRef]

120. Murphy, M.P. Targeting lipophilic cations to mitochondria. Biochim. Biophys. Acta 2008, 1777, $1028-1031$. [CrossRef] [PubMed]

121. Zhou, F.; Xing, D.; Wu, B.; Wu, S.; Ou, Z.; Chen, W.R. New insights of transmembranal mechanism and subcellular localization of noncovalently modified single-walled carbon nanotubes. Nano Lett. 2010, 10, 1677-1681. [CrossRef] [PubMed]

122. Chen, L.B. Mitochondrial membrane potential in living cells. Annu. Rev. Cell Biol. 1988, 4, 155-181. [CrossRef] [PubMed]

123. Appleby, R.D.; Porteous, W.K.; Hughes, G.; James, A.M.; Shannon, D.; Wei, Y.H.; Murphy, M.P. Quantitation and origin of the mitochondrial membrane potential in human cells lacking mitochondrial DNA. Eur. J. Biochem. 1999, 262, 108-116. [CrossRef] [PubMed]

124. Schneider Berlin, K.R.; Ammini, C.V.; Rowe, T.C. Dequalinium induces a selective depletion of mitochondrial DNA from HeLa human cervical carcinoma cells. Exp. Cell Res. 1998, 245, 137-145. [CrossRef] [PubMed]

125. Weissig, V.; Lizano, C.; Torchilin, V.P. Micellar delivery system for dequalinium-A lipophilic cationic drug with anticarcinoma activity. J. Liposome Res. 1998, 8, 391-400. [CrossRef]

126. Wang, X.X.; Li, Y.B.; Yao, H.J.; Ju, R.J.; Zhang, Y.; Li, R.J.; Yu, Y.; Zhang, L.; Lu, W.L. The use of mitochondrial targeting resveratrol liposomes modified with a dequalinium polyethylene glycol-distearoylphosphatidyl ethanolamine conjugate to induce apoptosis in resistant lung cancer cells. Biomaterials 2011, 32, 5673-5687. [CrossRef] [PubMed]

127. Deocaris, C.C.; Widodo, N.; Shrestha, B.G.; Kaur, K.; Ohtaka, M.; Yamasaki, K.; Kaul, S.C.; Wadhwa, R. Mortalin sensitizes human cancer cells to MKT-077-induced senescence. Cancer Lett. 2007, 252, 259-269. [CrossRef] [PubMed]

128. Fantin, V.R.; Leder, P. F16, a mitochondriotoxic compound, triggers apoptosis or necrosis depending on the genetic background of the target carcinoma cell. Cancer Res. 2004, 64, 329-336. [CrossRef] [PubMed]

129. Xiang, C.; Li, D.W.; Qi, Z.D.; Jiang, F.L.; Ge, Y.S.; Liu, Y. Synthesis of F16 conjugated with 5-fluorouracil and biophysical investigation of its interaction with bovine serum albumin by a spectroscopic and molecular modeling approach. Luminescence 2013, 28, 865-872. [CrossRef] [PubMed]

130. Hickey, J.L.; Ruhayel, R.A.; Barnard, P.J.; Baker, M.V.; Berners-Price, S.J.; Filipovska, A. Mitochondria-targeted chemotherapeutics: The rational design of gold (I) N-heterocyclic carbene complexes that are selectively toxic to cancer cells and target protein selenols in preference to thiols. J. Am. Chem. Soc. 2008, 130, 12570-12571. [CrossRef] [PubMed]

131. Marrache, S.; Pathak, R.K.; Dhar, S. Formulation and optimization of mitochondria-targeted polymeric nanoparticles. Methods Mol. Biol. 2015, 2, 103-112.

132. Marrache, S.; Pathak, R.K.; Dhar, S. Detouring of cisplatin to access mitochondrial genome for overcoming resistance. Proc. Natl. Acad. Sci. USA 2014, 111, 10444-10449. [CrossRef] [PubMed]

133. Feldhaeusser, B.; Platt, S.R.; Marrache, S.; Kolishetti, N.; Pathak, R.K.; Montgomery, D.J.; Reno, L.R.; Howerth, E.; Dhar, S. Evaluation of nanoparticle delivered cisplatin in beagles. Nanoscale 2015, 7, 13822-13830. [CrossRef] [PubMed] 
134. Pathak, R.K.; Dhar, S. A Nanoparticle Cocktail: Temporal Release of Predefined Drug Combinations. J. Am. Chem. Soc. 2015, 137, 8324-8327. [CrossRef] [PubMed]

135. Kalathil, A.A.; Kumar, A.; Banik, B.; Ruiter, T.A.; Pathak, R.K.; Dhar, S. New formulation of old aspirin for better delivery. Chem. Commun. 2016, 52, 140-143. [CrossRef] [PubMed]

136. Marrache, S.; Dhar, S. The energy blocker inside the power house: Mitochondria targeted delivery of 3-bromopyruvate. Chem. Sci. 2015, 6, 1832-1845. [CrossRef] [PubMed]

137. Marrache, S.; Dhar, S. Biodegradable synthetic high-density lipoprotein nanoparticles for atherosclerosis. Proc. Natl. Acad. Sci. USA 2013, 110, 9445-9450. [CrossRef] [PubMed]

138. Omura, T. Mitochondria-targeting sequence, a multi-role sorting sequence recognized at all steps of protein import into mitochondria. J. Biochem. 1998, 123, 1010-1016. [CrossRef] [PubMed]

139. Neupert, W. Protein import into mitochondria. Annu. Rev. Biochem. 1997, 66, 863-917. [CrossRef] [PubMed]

140. Kalafut, D.; Anderson, T.N.; Chmielewski, J. Mitochondrial targeting of a cationic amphiphilic polyproline helix. Bioorg. Med. Chem. Lett. 2012, 22, 561-563. [CrossRef] [PubMed]

141. von Heijne, G. Mitochondrial targeting sequences may form amphiphilic helices. EMBO J. 1986, 5, 1335-1342. [PubMed]

142. Yousif, L.F.; Stewart, K.M.; Kelley, S.O. Targeting Mitochondria with Organelle-Specific Compounds: Strategies and Applications. ChemBioChem 2009, 10, 1939-1950. [CrossRef] [PubMed]

143. Metón, I.; Egea, M.; Fernández, F.; Eraso, M.A.; Baanante, I.V. The N-terminal sequence directs import of mitochondrial alanine aminotransferase into mitochondria. FEBS Lett. 2004, 566, 251-254. [CrossRef] [PubMed]

144. Shokolenko, I.N.; Alexeyev, M.F.; LeDoux, S.P.; Wilson, G.L. TAT-mediated protein transduction and targeted delivery of fusion proteins into mitochondria of breast cancer cells. DNA Repair 2005, 4, 511-518. [CrossRef] [PubMed]

145. Takaya, K.; Higuchi, Y.; Kitamoto, K.; Arioka, M. A cytosolic phospholipase A2-like protein in the filamentous fungus Aspergillus oryzae localizes to the intramembrane space of the mitochondria. FEMS Microbiol. Lett. 2009, 301, 201-209. [CrossRef] [PubMed]

146. Marchenko, N.D.; Zaika, A.; Moll, U.M. Death signal-induced localization of p53 protein to mitochondria a potential role in apoptotic signaling. J. Biol. Chem. 2000, 275, 16202-16212. [CrossRef] [PubMed]

147. Zhao, K.; Zhao, G.M.; Wu, D.; Soong, Y.; Birk, A.V.; Schiller, P.W.; Szeto, H.H. Cell-permeable peptide antioxidants targeted to inner mitochondrial membrane inhibit mitochondrial swelling, oxidative cell death, and reperfusion injury. J. Biol. Chem. 2004, 279, 34682-34690. [CrossRef] [PubMed]

148. Thomas, D.A.; Stauffer, C.; Zhao, K.; Yang, H.; Sharma, V.K.; Szeto, H.H.; Suthanthiran, M. Mitochondrial targeting with antioxidant peptide SS-31 prevents mitochondrial depolarization, reduces islet cell apoptosis, increases islet cell yield, and improves posttransplantation function. J. Am. Soc. Nephrol. 2007, 18, 213-222. [CrossRef] [PubMed]

149. Xun, Z.; Rivera-Sánchez, S.; Ayala-Peña, S.; Lim, J.; Budworth, H.; Skoda, E.M.; Robbins, P.D.; Niedernhofer, L.J.; Wipf, P.; McMurray, C.T. Targeting of XJB-5-131 to mitochondria suppresses oxidative DNA damage and motor decline in a mouse model of huntington's disease. Cell Rep. 2012, 2, 1137-1142. [CrossRef] [PubMed]

150. Wipf, P.; Xiao, J.; Jiang, J.; Belikova, N.A.; Tyurin, V.A.; Fink, M.P.; Kagan, V.E. Mitochondrial targeting of selective electron scavengers: Synthesis and biological analysis of hemigramicidin-TEMPO conjugates. J. Am. Chem. Soc. 2005, 127, 12460-12461. [CrossRef] [PubMed]

151. Jiang, J.; Belikova, N.A.; Hoye, A.T.; Zhao, Q.; Epperly, M.W.; Greenberger, J.S.; Wipf, P.; Kagan, V.E. A mitochondria-targeted nitroxide/hemigramicidin $\mathrm{S}$ conjugate protects mouse embryonic cells against gamma irradiation. Int. J. Radiat. Oncol. Biol. Phys. 2008, 70, 816-825. [CrossRef] [PubMed]

152. Robin, M.A.; Anandatheerthavarada, H.K.; Fang, J.K.; Cudic, M.; Otvos, L.; Avadhani, N.G. Mitochondrial targeted cytochrome P450 2E1 (P450 MT5) contains an intact N terminus and requires mitochondrial specific electron transfer proteins for activity. J. Biol. Chem. 2001, 276, 24680-24689. [CrossRef] [PubMed]

153. Nargund, A.M.; Pellegrino, M.W.; Fiorese, C.J.; Baker, B.M.; Haynes, C.M. Mitochondrial import efficiency of ATFS-1 regulates mitochondrial UPR activation. Science 2012, 337, 587-590. [CrossRef] [PubMed]

154. Jiang, L.; Li, L.; He, X.; Yi, Q.; He, B.; Cao, J.; Pan, W.; Gu, Z. Overcoming drug-resistant lung cancer by paclitaxel loaded dual-functional liposomes with mitochondria targeting and $\mathrm{pH}$-response. Biomaterials 2015, 52, 126-139. [CrossRef] [PubMed] 
155. Nakase, I.; Okumura, S.; Katayama, S.; Hirose, H.; Pujals, S.; Yamaguchi, H.; Arakawa, S.; Shimizu, S.; Futaki, S. Transformation of an antimicrobial peptide into a plasma membrane-permeable, mitochondria-targeted peptide via the substitution of lysine with arginine. Chem. Commun. 2012, 48, 11097-11099. [CrossRef] [PubMed]

156. Lee, C.; Zeng, J.; Drew, B.G.; Sallam, T.; Martin-Montalvo, A.; Wan, J.; Kim, S.J.; Mehta, H.; Hevener, A.L.; de Cabo, R.; et al. The mitochondrial-derived peptide MOTS-c promotes metabolic homeostasis and reduces obesity and insulin resistance. Cell Metab. 2015, 21, 443-454. [CrossRef] [PubMed]

157. Flierl, A.; Jackson, C.; Cottrell, B.; Murdock, D.; Seibel, P.; Wallace, D.C. Targeted delivery of DNA to the mitochondrial compartment via import sequence-conjugated peptide nucleic acid. Mol. Ther. 2003, 7, 550-557. [CrossRef]

158. Horton, K.L.; Stewart, K.M.; Fonseca, S.B.; Guo, Q.; Kelley, S.O. Mitochondria-penetrating peptides. Chem. Biol. 2008, 15, 375-382. [CrossRef] [PubMed]

159. Kawamura, E.; Yamada, Y.; Yasuzaki, Y.; Hyodo, M.; Harashima, H. Intracellular observation of nanocarriers modified with a mitochondrial targeting signal peptide. J. Biosci. Bioeng. 2013, 116, 634-637. [CrossRef] [PubMed]

160. Yamada, Y.; Harashima, H. Enhancement in selective mitochondrial association by direct modification of a mitochondrial targeting signal peptide on a liposomal based nanocarrier. Mitochondrion 2013, 13, 526-532. [CrossRef] [PubMed]

161. Shedlock, D.J.; Shen, H. Requirement for CD4 T cell help in generating functional CD8 T cell memory. Science 2003, 300, 337-339. [CrossRef] [PubMed]

162. Brossart, P.; Wirths, S.; Brugger, W.; Kanz, L. Dendritic cells in cancer vaccines. Exp. Hematol. 2001, 29, 1247-1255. [CrossRef]

163. Banchereau, J.; Steinman, R.M. Dendritic cells and the control of immunity. Nature 1998, 392, $245-252$. [CrossRef] [PubMed]

164. Valitutti, S.; Müller, S.; Cella, M.; Padovan, E.; Lanzavecchia, A. Serial triggering of many T-cell receptors by a few peptide MHC complexes. Nature 1995, 375, 148-151. [CrossRef] [PubMed]

165. Zhang, X.; Gordon, J.R.; Xiang, J. Advances in dendritic cell-based vaccine of cancer. Cancer Biother. Radiopharm. 2002, 17, 601-619. [CrossRef] [PubMed]

166. Steinman, R.M.; Banchereau, J. Taking dendritic cells into medicine. Nature 2007, 449, 419-426. [CrossRef] [PubMed]

167. Butterfield, L.H. Dendritic cells in cancer immunotherapy clinical trials: Are we making progress? Front. Immunol. 2013. [CrossRef] [PubMed]

168. Gregoire, M.; Ligeza-Poisson, C.; Juge-Morineau, N.; Spisek, R. Anti-cancer therapy using dendritic cells and apoptotic tumour cells: Pre-clinical data in human mesothelioma and acute myeloid leukaemia. Vaccine 2003, 21, 791-794. [CrossRef]

169. Figdor, C.G.; de Vries, I.J.; Lesterhuis, W.J.; Melief, C.J. Dendritic cell immunotherapy: Mapping the way. Nat. Med. 2004, 10, 475-480. [CrossRef] [PubMed]

170. Lanzavecchia, A.; Sallusto, F. Regulation of T cell immunity by dendritic cells. Cell 2001, 106, $263-266$. [CrossRef]

171. Mayordomo, J.; Zorina, T.; Storkus, W.; Zitvogel, L.; Celluzzi, C.; Falo, L.; Melief, C.; Ildstad, S.; Kast, W.M.; Deleo, A. Bone marrow-derived dendritic cells pulsed with synthetic tumour peptides elicit protective and therapeutic antitumour immunity. Nat. Med. 1995, 1, 1297-1302. [CrossRef] [PubMed]

172. Rahma, O.E.; Herrin, V.E.; Ibrahim, R.A.; Toubaji, A.; Bernstein, S.; Dakheel, O.; Steinberg, S.M.; Abu, E.R.; Mkrtichyan, M.; Berzofsky, J.A. Pre-immature dendritic cells (PIDC) pulsed with HPV16 E6 or E7 peptide are capable of eliciting specific immune response in patients with advanced cervical cancer. J. Transl. Med. 2014, 12, 1-10. [CrossRef] [PubMed]

173. Rong, Y.; Qin, X.; Jin, D.; Lou, W.; Wu, L.; Wang, D.; Wu, W.; Ni, X.; Mao, Z.; Kuang, T. A phase I pilot trial of MUC1-peptide-pulsed dendritic cells in the treatment of advanced pancreatic cancer. Clin. Exp. Med. 2012, 12, 173-180. [CrossRef] [PubMed]

174. Phuphanich, S.; Wheeler, C.J.; Rudnick, J.D.; Mazer, M.; Wang, H.; Nuno, M.A.; Richardson, J.E.; Fan, X.; Ji, J.; Chu, R.M. Phase I trial of a multi-epitope-pulsed dendritic cell vaccine for patients with newly diagnosed glioblastoma. Cancer Immunol. Immunother. 2013, 62, 125-135. [CrossRef] [PubMed] 
175. Tamayo, I.; Irache, J.M.; Mansilla, C.; Ochoa-Repáraz, J.; Lasarte, J.J.; Gamazo, C. Poly (anhydride) nanoparticles act as active Th1 adjuvants through Toll-like receptor exploitation. Clin. Vaccine Immunol. 2010, 17, 1356-1362. [CrossRef] [PubMed]

176. Clements, C.; Griffiths, E. The global impact of vaccines containing aluminium adjuvants. Vaccine 2002, 20, 24-33. [CrossRef]

177. Li, H.; Li, Y.; Jiao, J.; Hu, H.M. Alpha-alumina nanoparticles induce efficient autophagy-dependent cross-presentation and potent antitumour response. Nat. Nanotechnol. 2011, 6, 645-650. [CrossRef] [PubMed]

178. Hamblin, M.R.; Hasan, T. Photodynamic therapy: A new antimicrobial approach to infectious disease? Photochem. Photobiol. Sci. 2004, 3, 436-450. [CrossRef] [PubMed]

179. Juarranz, Á.; Jaén, P.; Sanz-Rodríguez, F.; Cuevas, J.; González, S. Photodynamic therapy of cancer. Basic principles and applications. Clin. Transl. Onco. 2008, 10, 148-154. [CrossRef]

180. Triesscheijn, M.; Baas, P.; Schellens, J.H.; Stewart, F.A. Photodynamic therapy in oncology. Oncologist 2006, 11, 1034-1044. [CrossRef] [PubMed]

181. Pozzi, L.A.; Maciaszek, J.W.; Rock, K.L. Both dendritic cells and macrophages can stimulate naive CD8 T cells in vivo to proliferate, develop effector function, and differentiate into memory cells. J. Immunol. 2005, 175, 2071-2081. [CrossRef] [PubMed]

182. Fievez, V.; Plapied, L.; des Rieux, A.; Pourcelle, V.; Freichels, H.; Wascotte, V.; Vanderhaeghen, M.L.; Jerôme, C.; Vanderplasschen, A.; Marchand-Brynaert, J. Targeting nanoparticles to M cells with non-peptidic ligands for oral vaccination. Eur. J. Pharm. Biopharm. 2009, 73, 16-24. [CrossRef] [PubMed]

183. Chen, W.C.; Kawasaki, N.; Nycholat, C.M.; Han, S.; Pilotte, J.; Crocker, P.R.; Paulson, J.C. Antigen delivery to macrophages using liposomal nanoparticles targeting sialoadhesin/CD169. PLoS ONE 2012, 7, e39039. [CrossRef] [PubMed]

184. Zhou, H.; Zhao, K.; Li, W.; Yang, N.; Liu, Y.; Chen, C.; Wei, T. The interactions between pristine graphene and macrophages and the production of cytokines/chemokines via TLR-and NF-kB-related signaling pathways. Biomaterials 2012, 33, 6933-6942. [CrossRef] [PubMed]

185. Hanley, C.; Thurber, A.; Hanna, C.; Punnoose, A.; Zhang, J.; Wingett, D. The Influences of Cell Type and ZnO Nanoparticle Size on Immune Cell Cytotoxicity and Cytokine Induction. Nanoscale Res. Lett. 2009, 4, 1409-1420. [CrossRef] [PubMed]

186. Roy, R.; Tripathi, A.; Das, M.; Dwivedi, P.D. Cytotoxicity and uptake of zinc oxide nanoparticles leading to enhanced inflammatory cytokines levels in murine macrophages: Comparison with bulk zinc oxide. J. Biomed. Nanotechnol. 2011, 7, 110-111. [CrossRef] [PubMed]

187. Liu, Y.; Jiao, F.; Qiu, Y.; Li, W.; Lao, F.; Zhou, G.; Sun, B.; Xing, G.; Dong, J.; Zhao, Y.; et al. The effect of $\mathrm{Gd} @ \mathrm{C}_{82}(\mathrm{OH})_{22}$ nanoparticles on the release of Th1/Th2 cytokines and induction of TNF- $\alpha$ mediated cellular immunity. Biomaterials 2009, 30, 3934-3945. [CrossRef] [PubMed]

188. Liu, Y.; Balachandran, Y.L.; Li, D.; Shao, Y.; Jiang, X. Polyvinylpyrrolidone-poly (ethylene glycol) modified silver nanorods can be a safe, noncarrier adjuvant for HIV vaccine. ACS Nano 2016, 10, 3589-3596. [CrossRef] [PubMed]

189. Parry, A.L.; Clemson, N.A.; Ellis, J.; Bernhard, S.S.; Davis, B.G.; Cameron, N.R. Multicopy multivalent' glycopolymer-stabilized gold nanoparticles as potential synthetic cancer vaccines. J. Am. Chem. Soc. 2013, 135, 9362-9365. [CrossRef] [PubMed]

(C) 2016 by the authors; licensee MDPI, Basel, Switzerland. This article is an open access article distributed under the terms and conditions of the Creative Commons Attribution (CC-BY) license (http://creativecommons.org/licenses/by/4.0/). 